\title{
Sheepskin Effects and the Relationship between Earnings and Education: Analyzing their Evolution over Time in Brazil* $^{*}$
}

\author{
Anna Crespo ${ }^{\dagger}$, Mauricio Cortez Reis ${ }^{\ddagger}$
}

\author{
Contents: 1. Introduction; 2. Data; 3. Empirical Evidence; 4. Conclusion; A. Tables. \\ Keywords: sheepskin effect; earnings; education. \\ JEL Code: I20; J30.
}

Este artigo procura analisar tendências no efeito-diploma e na relação entre rendimentos e educação no mercado de trabalho brasileiro durante o período de 1982 até 2004. Usando dados da PNAD (Pesquisa Nacional por Amostra de Domicílios) são estimadas equações de rendimentos usando, além de um termo linear para os anos de escolaridade, mudanças de inclinação e saltos para graus completos do ciclo educacional. Também são estimadas regressões semi-paramétricas, que flexibilizam a relação entre rendimentos e educação. As evidências empíricas mostram uma redução do efeito-diploma entre 1982 e 2004, indicando que a conclusão de um grau ou a obtenção de um diploma vem perdendo valor ao longo do tempo. Ao mesmo tempo, a relação entre o logaritmo dos rendimentos e os anos de escolaridade tem se tornado mais convexa. Tendências semelhantes são verificadas quando a análise é implementada separadamente por região. This paper seeks to analyze trends in sheepskin effects and in the relationship between earnings and education on the Brazilian labor Market from 1982 to 2004. Using data from the PNAD - the Brazilian National Household Sample Survey - earnings equations are estimated including linear years of schooling, and splines and discontinuous functions for completed degrees, as well as semiparametric regressions. Empirical evidence shows a reduction in sheepskin effects from 1982 to 2004, indicating that a diploma or degree completion in Brazil has been losing its value over time. At the same time, the relationship between log earnings and education has become more convex. Similar trends are verified when the analysis is carried out separately by region.

\footnotetext{
* Os autores agradecem os comentários e sugestões de Gustavo Gonzaga e participantes do XXXIII Congresso da ANPEC. Mauricio Reis agradece o apoio financeiro do CNPq.

${ }^{\dagger}$ Princeton University. E-mail: acrespo@princeton.edu

${ }^{\ddagger}$ IPEA. E-mail: mcreis@ipea.gov .br
} 


\section{INTRODUCTION}

There are a vast number of papers in the literature showing that earnings and education are positively related (see Card (1999)). Following Mincer's (1974) model, most of those papers represent the $\log$ of earnings as a linear function of education. Nevertheless, according to the sheepskin effect hypothesis, an additional year of schooling has an even stronger impact on earnings if it corresponds to a diploma or degree completion. The argument is that employers may use the information offered by a diploma or degree as a signal positively related to workers' unobserved productivity. ${ }^{1}$ Therefore, sheepskin effects imply a nonlinear and discontinuous relationship between education and the log of earnings, as opposed to the standard linear earnings function established by Mincer (1974).

Evidence for different countries is consistent with the presence of sheepskin effects. ${ }^{2}$ In Brazil, estimates reported by Lam and Schoeni (1993) and Ramos and Vieira (1996) show that returns to schooling ${ }^{3}$ are highly nonlinear, with the completion of a degree representing a substantial earnings gain. Ramos and Vieira (1996), using PNAD data for 1990, find that an upper primary school degree (8 years of completed schooling) increases earnings by $6 \%$, and secondary school (11 years of schooling) and college (15 years of schooling) degrees increase earnings by 18\%. Comparing 1976 with 1990 these authors show that sheepskin effects are very stable across time, except for the lower primary degree (4 years of schooling), which decreased slightly.

There is also a body of evidence showing that the log of earnings have become an increasingly convex function of years of schooling in the United States since 1980 (Mincer, 1974, Lemieux, 2006, Deschênes, 2006). Autor et al. (2006) argue that computerization has displaced semi-skilled workers from performing routine tasks. Since computers complement skilled workers in performing nonroutine tasks, but neither substitute nor complement unskilled workers engaged in manual tasks, changes in the earnings structure could be attributed to labor demand shifts associated with computerization. The structure of the Brazilian labor market has been changing considerably in the last decades, which could have changed the returns to education. From 1982 to 2004 the educational level of the labor force experienced a remarkable increase. In 1982 more than one third of the workers had not finished lower primary school, which requires four years of completed schooling. In 2004, this proportion decreased to about $15 \%$. It is possible to notice also that changes in educational distribution during this period were much more intense across workers with completed degrees than for other individuals who did not have this kind of credential. These facts may have changed the signal value represented by the completion of a given degree, and then sheepskin effects are expected to lose their importance, in particular for lower degrees. A lower primary degree could be a positive signal for individual unobserved characteristics in 1982, since a great share of the workers did not reach this level of education, but probably, it offers a very different kind of information for employers in 2004.

At the same time, important changes have been occurring on the labor demand side, especially after the 1990s, when the trade liberalization process was intensified in the country and the technological progress was amplified. As documented in many papers, the technological progress should increase the relative demand for more skilled workers. ${ }^{4}$ It is also possible that the technological progress could have contributed to increasing the convexity of the relationship between the log of earnings and edu-

\footnotetext{
${ }^{1}$ The completion of a degree could increase the signal value, since it should indicate, for example, workers' perseverance and motivation, which are factors that enhance productivity (Weiss, 1995).

${ }^{2}$ See, for instance, Hungerford and Solon (1987), Belman and Heywood (1991), Jaeger and Page (1996) and Park (1999) for the United States, Ferrer and Riddell (2002) for Canada, Schady (2003) for the Philippines and Pons (2006) for Spain.

${ }^{3}$ It should be stressed that, although labor economists refer to the effect of an additional year of education on earnings as the "return to schooling", a carefully calculation of the "return" would incorporate the tuition cost of schooling.

${ }^{4}$ See, for example, Berman et al. (1994) and Autor et al. (1998). Evidence from Brazil provided by Fernandes and Menezes-Filho (2002) and Menezes-Filho and Rodrigues (2003) is consistent with this argument.
} 
cation, as in Autor et al. (2006), as well as to increasing the sheepskin effects for high level degrees and decreasing them for low level ones.

The objective of this paper is to analyze the evolution of sheepskin effects and the relationship between education and earnings in the Brazilian labor market from 1982 to 2004. In order to proceed with the empirical analysis, this paper uses data from PNAD - the Brazilian National Household Sample Survey. The empirical strategy adopted to identify the sheepskin effects consists in estimating earnings equations, including linear years of schooling, and splines and discontinuous functions for completed degrees, using demographic and labor market experience controls.

The results show that sheepskin effects represent a substantial earnings gain. Also, the patterns of sheepskin effects changed very much from 1982 to 2004, with their importance reducing over time. The lower degree, corresponding to the lower primary school, which influenced earnings in a significant way in the early 1980s, became unimportant in 2004. The effects of higher degrees also decreased from 1982 to 2004, but they are still relatively elevated in this last period. Empirical evidence also indicates a growing convexity in the relationship between education and earnings over time. Similar trends are found when the analysis is carried out separately by region.

The paper is structured as follows. The next section presents the PNAD data used in this paper, and describes educational distribution differences across periods and regions. Section 3 discusses the empirical strategy implemented in the paper. The subsequent section presents the results for the evolution of sheepskin effects and the relationship between earnings and schooling during the last decades. Section 6 summarizes and concludes the paper.

\section{DATA}

This paper uses data from the 1982, 1992, 1998 and 2004 PNAD. This survey is conducted every September by the Brazilian Census Bureau (IBGE) and the sample is representative of the Brazilian population. The sample used in this paper includes workers aged 25 to 60 years, living in urban areas. All employers were excluded from the sample.

For each individual in the sample there is information about the following variables: earnings, hourly earnings, age, gender, race, region, number of years of completed schooling and potential labor market experience. This last variable is calculated using the difference between age and the age at which the worker started to work. ${ }^{5}$ The data contain information about 71,366 individuals in 1982; 55,542 in 1992; 63,920 in 1998 and 83,988 individuals in 2004.

Four degrees are considered in this paper. The first degree (lower primary school) corresponds to 4 years of completed schooling. Although it had vanished during an educational system reform at the beginning of the 1970s, the first segment of primary school is included in the empirical analysis because there is a great share of workers with exactly 4 years of completed schooling, especially in older generations, and this could still be used as reference. The second degree is the upper primary school, which corresponds to 8 years of completed schooling. The next degree (secondary school) is obtained with 11 years of completed schooling, and finally, the fourth degree (college) is acquired with 15 years of completed schooling. PNAD does not distinguish between Master's and PhD diplomas, and attributes 17 years of schooling to these degrees. Although these groups of workers are included in the sample, these degrees are not used in the paper to account for sheepskin effects. In addition, there are very few individuals with these levels of education in the sample.

Figure 1 presents the mean log of earnings in the main job according to years of completed schooling. From 1982 to 1992, after a period of intense macroeconomic crisis in the early 1990s, mean earnings

\footnotetext{
${ }^{5}$ In 1982, PNAD information about potential labor market experience was available only for the head of the household and his or her spouse, which corresponds to about $85 \%$ of the total of individuals. Then, the same filter is applied for 1992, 1998 and 2004. Estimates including other persons in the household are very similar for these last three years.
} 
Figure 1: Mean log earnings and years of schooling

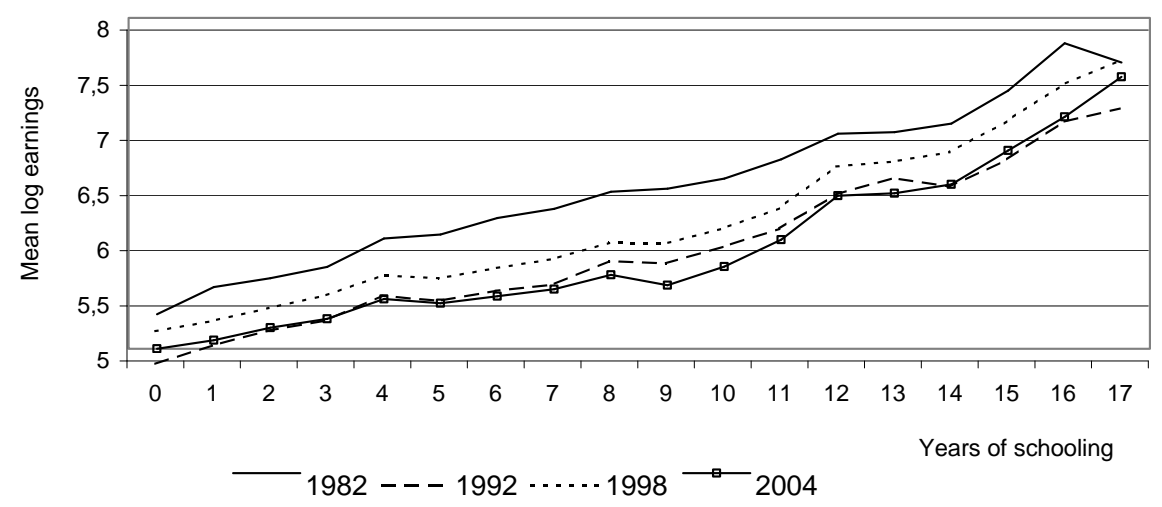

Source: Based on PNAD data for workers aged 25 to 60 years old, living in urban areas, who are the head of the household or the spouse of the head.

decreased for each year of education. Mean earnings recovered in 1998 and dropped again in 2004. Figure 1 shows also that the relationship between the log of earnings and education was almost linear in 1982. But it is possible to notice an increased convexity in this relationship over time. In 1982, mean earnings for workers with 10 years of schooling were around $123 \%$ higher than for those who did not complete the first year of education. In 2004, this difference fell to $75 \%$. Mean earnings for workers with 17 years of schooling in 1982 were twice higher than those with 10 years of schooling, but in 2004 the difference between these two groups increased to $172 \%$.

Table 1 reports the descriptive statistics for some variables for each year considered in this paper. Evidence for the total sample, in the top panel, shows that mean earnings decreased from R\$ 690 in 1982 to R 458 in 2004. A similar trend is verified for mean hourly earnings. Average years of schooling increased from 5.2 in 1982 to 7.7 in 2004, while age and potential labor market experience increased slightly during this period.

Table 1 also presents descriptive statistics comparing the Southeast and the Northeast regions. These two regions comprise around $70 \%$ of the Brazilian labor force. ${ }^{6}$ The differences in mean earnings and years of schooling between the two regions are impressive. In 1982 earnings in the Southeast were 65\% higher than in the Northeast, and in 2004 this ratio increased to 75\%. From 1982 to 2004 the Southeast had one and a half more years of schooling than the Northeast. Table A-3 in the Appendix shows that earnings in the South and in the Center West were slightly lower than in the Southeast, while average years of schooling in the former two regions were similar to that of the Southeast. Earnings and average education in the North were higher than in the Northeast, but much lower than in the Southeast.

Figure 2 shows the fraction of workers in the labor force with each number of completed years of schooling in 1982, 1992, 1998 and 2002. Completed degrees are represented by dark bars. The educational level among Brazilian workers was extremely low in 1982. More than $35 \%$ of the workers had less than 4 years of completed schooling and more than $80 \%$ had less than 11 years of education. From 1982 to 2004 the educational level of the labor force increased, although it was still considerably low in 2004. The proportions with less than 4 and 11 years of schooling decreased to about 20 and $60 \%$, respectively.

\footnotetext{
${ }^{6}$ Summary statistics for other regions are reported in the Appendix.
} 
Table 1: Descriptive statistics

\begin{tabular}{|c|c|c|c|c|}
\hline & 1982 & 1992 & 1998 & 2004 \\
\hline \multicolumn{5}{|l|}{ Brazil } \\
\hline \multirow[t]{2}{*}{ Earnings in the main job } & 689,55 & 489,17 & 626,64 & 458,83 \\
\hline & $(985.64)$ & $(844.05)$ & $(960.06)$ & $(704.14)$ \\
\hline \multirow[t]{2}{*}{ Hourly earnings in the main job } & 16,28 & 12,41 & 16,75 & 12,75 \\
\hline & $(25.90)$ & $(20.42)$ & $(28.88)$ & $(40.77)$ \\
\hline \multirow[t]{2}{*}{ Years of schooling } & 5,187 & 6,241 & 6,910 & 7,677 \\
\hline & $(4.48)$ & $(4.60)$ & $(4.53)$ & $(4.47)$ \\
\hline \multirow[t]{2}{*}{ Age } & 38,649 & 38,643 & 39,372 & 39,785 \\
\hline & $(9.31)$ & $(9.01)$ & $(8.99)$ & $(9.14)$ \\
\hline \multirow[t]{2}{*}{ Experience } & 24,885 & 24,478 & 25,240 & 25,368 \\
\hline & $(10.67)$ & $(10.27)$ & $(10.18)$ & $(10.25)$ \\
\hline Number of observations & 77837 & 59308 & 68862 & 89483 \\
\hline \multicolumn{5}{|l|}{ Northeast } \\
\hline \multirow[t]{2}{*}{ Earnings in the main job } & 466,70 & 321,24 & 394,80 & 297,21 \\
\hline & (716.97) & $(534.65)$ & (665.16) & $(497.19)$ \\
\hline \multirow[t]{2}{*}{ Hourly earnings in the main job } & 11,51 & 8,68 & 11,03 & 8,83 \\
\hline & $(20.99)$ & $(16.51)$ & $(21.01)$ & $(29.38)$ \\
\hline \multirow[t]{2}{*}{ Years of schooling } & 4,06 & 5,34 & 5,98 & 6,68 \\
\hline & $(4.40)$ & $(4.75)$ & $(4.72)$ & $(4.69)$ \\
\hline \multirow[t]{2}{*}{ Age } & 39,26 & 38,62 & 39,22 & 39,39 \\
\hline & $(9.40)$ & (9.09) & $(9.18)$ & $(9.23)$ \\
\hline \multirow[t]{2}{*}{ Experience } & 25,20 & 24,26 & 24,97 & 24,91 \\
\hline & $(10.98)$ & $(10.61)$ & $(10.66)$ & $(10.55)$ \\
\hline Number of observations & 17076 & 15002 & 18817 & 25271 \\
\hline \multicolumn{5}{|l|}{ Southeast } \\
\hline \multirow[t]{2}{*}{ Earnings in the main job } & 772,09 & 563,96 & 733,54 & 517,75 \\
\hline & $(1087.77)$ & $(811.62)$ & $(1079.21)$ & $(729.48)$ \\
\hline \multirow[t]{2}{*}{ Hourly earnings in the main job } & 18,17 & 14,11 & 19,51 & 14,42 \\
\hline & $(28.31)$ & (19.95) & $(30.62)$ & $(51.77)$ \\
\hline \multirow[t]{2}{*}{ Years of schooling } & 5,53 & 6,54 & 7,30 & 8,04 \\
\hline & $(4.47)$ & $(4.56)$ & $(4.47)$ & $(4.34)$ \\
\hline \multirow[t]{2}{*}{ Age } & 38,64 & 38,89 & 39,68 & 40,18 \\
\hline & $(9.31)$ & $(8.96)$ & $(8.92)$ & $(9.08)$ \\
\hline \multirow[t]{2}{*}{ Experience } & 24,98 & 24,62 & 25,32 & 25,57 \\
\hline & $(10.56)$ & $(10.17)$ & $(10.04)$ & $(10.09)$ \\
\hline Number of observations & 30034 & 22796 & 25497 & 30051 \\
\hline
\end{tabular}

: Notes: based on PNAD data for individuals aged 25 to 60 years old, living in urban area, who are the head of the household or the spouse of the head. Standard errors are in parenteses. Earnings in 1999 Reais.

It is interesting to notice spikes in years corresponding to completion of a degree in all periods. In 1982, the highest concentration occurred for those with a lower primary degree - near one quarter of the labor force. The proportion of workers with less than one year of education was also very high (about 17\%). Seven per cent of the workers had 8 years of education in 1982, while $9 \%$ of them had 11 years of schooling. From 1982 to 2004 the change in educational distribution was mainly driven by reductions of 9 and 13 percentage points in the shares of workers with 0 and 4 years of schooling and a 15 percentage points increase in the proportion of workers with a secondary degree.

Remarkable differences in the educational distribution between the Southeast and the Northeast are shown in Figure 3. Notice, for example, that $30 \%$ of the labor force in the Northeast had less than one year of schooling in 1982, while this proportion was $13 \%$ in the Southeast. The shares of workers with 8,11 and 15 years of schooling increased in a similar magnitude in the two regions from 1982 to 2004 . But for individuals with 4 years of schooling the reduction was more intense in the Southeast. The 
Figure 2: Educational distribution of the labor force
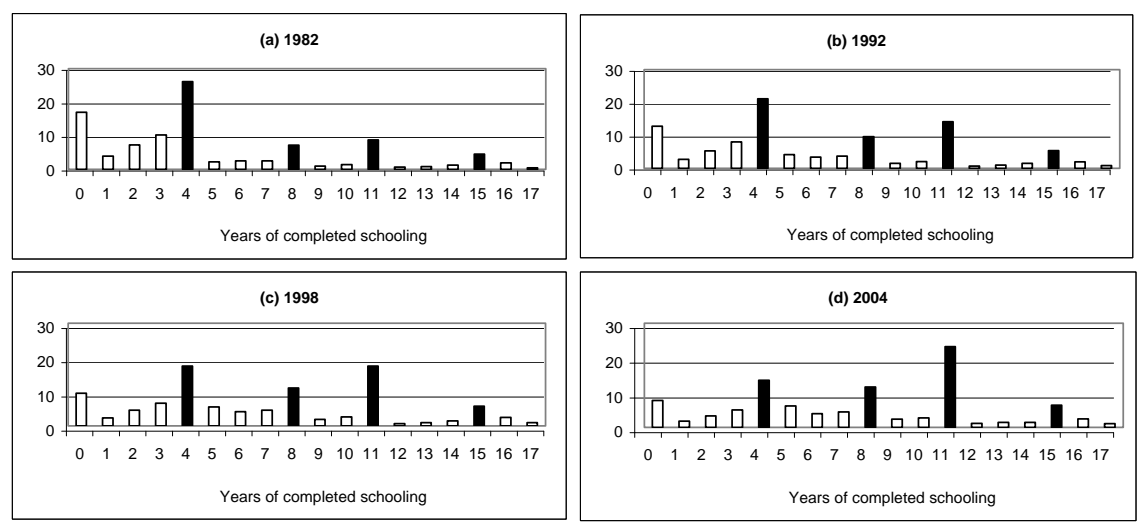

Source: PNAD data for workers aged 25 to 60 years old, living in urban areas, who are the head of the household or the spouse of the head.

Appendix shows that changes in the South and in the North were like those verified in the Southeast, while shifts in the Center West were similar to those observed in the Northeast.

\subsection{Empirical framework}

In order to investigate sheepskin effects we use the standard approach adopted by Hungerford and Solon (1987) and Belman and Heywood (1991). It consists in estimating earnings equations that allow for spline functions with discontinuities in years of completed schooling corresponding to a diploma or degree completion. Spline functions may capture convexity in the relationship between earnings and education.

The dependent variable in basic regressions is the logarithm of earnings in the main job. ${ }^{7}$ Regressions include years of completed schooling $(S)$, experience $(\operatorname{Exp})$, experience squared $(\operatorname{Exp} 2)$ and an interactive term between schooling and experience. The sheepskin effects are estimated by including four dummies corresponding to completed degrees. The first dummy $(D 4)$ is equal to 1 if $S \geq 4$, the second (D8) is equal to 1 if $S \geq 8$, the third $(D 11)$ is equal to 1 if $S \geq 11$ and finally, there is a dummy (D15) which is equal to 1 if $S \geq 15$. In order to allow for slope changes in the returns to the lower primary school, $D 4$ is interacted with a variable equal to years of schooling minus 4 . The same procedure is used for splines in upper primary, secondary and college degrees. A dummy variable for individuals with 16 years of schooling is also included. The regressions include controls for gender, race and region, represented by $X_{i}$.

Belman and Heywood (1997) argue that sheepskin effects are important signals of productivity for younger cohorts, but once workers accumulate experience in the labor market, the returns to these signals decrease, because employers have more information about employees' productivity. In order to account for this effect, the dummies $D 4, D 8, D 11$ and $D 15$ are interacted with potential labor market experience.

Representing the earnings for individual $i$ by $w_{i}$, the estimated specification is as follows:

\footnotetext{
${ }^{7}$ Regressions that use the logarithm of hourly earnings as dependent variable are reported in the Appendix and the results are similar.
} 
Figure 3: Educational distribution of the labor force by region
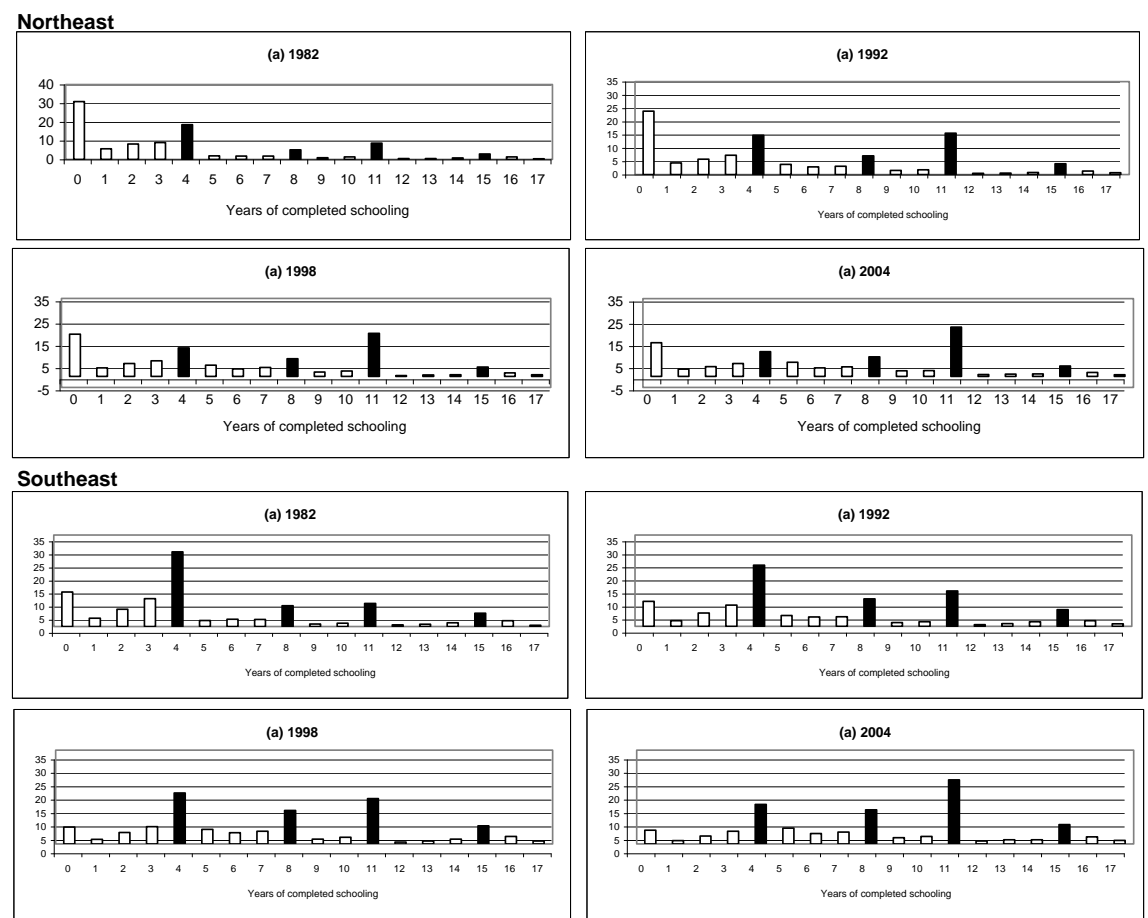

Source: PNAD data for workers aged 25 to 60 years old, living in urban areas, who are the head of the household or the spouse of the head.

$$
\begin{aligned}
\ln \left(w_{i}\right)= & \beta_{0}+\beta_{1} S_{i}+\beta_{2} \operatorname{Exp}_{i}+\beta_{3} \operatorname{Exp}_{i}^{2}+\beta_{4} \operatorname{Exp}_{i} * S_{i}+\beta_{5} D 4_{i}+\beta_{6} D 8_{i}+\beta_{7} D 11_{i} \\
& +\beta_{8} D 15_{i}+\beta_{9} D 4_{i} *\left(S_{i}-4\right)+\beta_{10} D 8_{i} *\left(S_{i}-8\right)+\beta_{11} D 11_{i} *\left(S_{i}-11\right) \\
& +\beta_{12} D 15_{i} *\left(S_{i}-15\right)+\beta_{13} S 16+\beta_{14} \operatorname{Exp} * D 4_{i}+\beta_{15} \operatorname{Exp} * D 8_{i} \\
& +\beta_{16} \operatorname{Exp} * D 11_{i}+\beta_{17} \operatorname{Exp} * D 15_{i}+\gamma X_{i}+\epsilon_{i}
\end{aligned}
$$

We also estimate a more flexible specification. In this semiparametric model the log of earnings is regressed on an unrestricted set of schooling dummies:

$$
\ln \left(w_{i}\right)=\beta_{0}+\sum_{j=1}^{17} \beta_{j} S_{j i}+\beta_{18} \operatorname{Exp}_{i}+\beta_{19} \operatorname{Exp}_{i}^{2}+\beta_{20} \operatorname{Exp}_{i} * S_{i}+\gamma X_{i}+\epsilon_{i}
$$

where $S_{j}$ represents dummy variables for years of education $j(j=1, \ldots 17)$. Regressions are estimated for 1982, 1992, 1998 and 2002 for Brazil as a whole, and later separately for each region in all these years. Therefore, evolutions of sheepskin effect coefficients are compared over time. The results of these regressions are presented and discussed in the next section. 


\section{EMPIRICAL EVIDENCE}

The estimated results are presented in two subsections. Subsection 3.1 reports the evidence for the sample of workers in Brazil. The next subsection presents evidence for the Northeast and the Southeast, comparing the results for these two regions. Regressions for other regions are shown in the Appendix.

\subsection{The evolution of sheepskin effects and the earnings-education profile in the Brazilian labor market}

Table 2 presents the estimated results for equation (1) in 1982, 1992, 1998 and 2004. Evidence supporting sheepskin effects could be verified in all four years reported. According to Table 2, the sheepskin effects were higher for more advanced degrees, and they showed a downtrend from 1982 to 2004. The lower primary school degree increased earnings by $12 \%$ in 1982, and became nonsignificant after the 1990 s. $^{8}$ The upper primary degree effect was $12 \%$ in 1982 , and increased slightly in 2004 , when it was equal to $14 \%$. The reductions in the coefficients for completed degrees were intense for higher credentials, but sheepskin effects were still very impressive in 2004. The secondary degree effect, which was $32 \%$ in 1982 , dropped to $27 \%$ in 2004 . The college degree represented an earnings increase of $31 \%$ in 1982 . Twenty-two years later this effect decreased to $19 \%$.

Changes in slope associated with a completed degree were different across periods as well. There was a drop in the spline related to lower primary school from 1982 to 2004 . On the other hand, splines for secondary school and college presented an increasing trend, indicating that the reduction in sheepskin effects was accompanied by an increase in the nonlinearity of the log of earnings returns to education. Figure A-2 in the Appendix plots the log of the earnings-education relationship estimated in Table 2 for 1982 and 2004. The increased nonlinearity in returns to education seems very clear in this figure. F-tests reported in Table 2 indicate that sheepskin effects and spline functions related to a completed degree influence earnings in a significant way.

Table 2 also shows that interactive terms between completed degrees and experience are negative and significant in most of the regressions. So, although workers with a diploma or a degree have an extra gain in their earnings, this effect decreases with labor market experience, as predicted by Belman and Heywood (1997).

Table 3 presents the results based on semiparametric regressions for 1982, 1992, 1998 and 2004. Except for the highest level of education, it is possible to notice that estimated coefficients for each year of schooling are lower in 2004 than in 1982. This gap has an increasing trend from 1 to 10 years of education, while after 11 years the tendency is reversed. The top left graph in Figure A-3 shows the increasing convexity in the earnings-education relationship from 1982 to 2004.

Summing up, there was a reduction in the sheepskin effects from 1982 to 2004 . This result could be due to the fact that the proportion of more educated workers increased over time, reducing the signal value represented by the completion of a degree. In addition, evidence shows that the relationship between earnings and education has become more convex over time.

\subsection{The evolution of sheepskin effects and the earnings-education profile by re- gion}

Regressions for the Northeast and the Southeast are presented in Table 4. Earnings gains associated with sheepskin effects in the Southeast have a decreasing trend over time for all degrees. Trends are not so clear in the Northeast, but indicate a reduction in sheepskin effects, too. In the Southeast as well as in the Northeast, returns to lower primary school were positive in 1982 and have become nonsignificant

\footnotetext{
${ }^{8}$ It is important to notice that this result could be due to the fact that lower primary education weakened part of its status during the educational system reform.
} 
Table 2: Earnings equation

\begin{tabular}{|c|c|c|c|c|}
\hline \multicolumn{5}{|c|}{ Dependent variable: log of earnings in the main job } \\
\hline & 1982 & 1992 & 1998 & 2004 \\
\hline & (1) & (2) & (3) & (4) \\
\hline \multirow[t]{2}{*}{ Years of schooling (S) } & 0,0659 & 0,0477 & 0,0397 & 0,0479 \\
\hline & {$[7.05]^{3}$} & {$[3.94]^{3}$} & {$[3.72]^{3}$} & {$[4.99]^{3}$} \\
\hline \multirow[t]{2}{*}{ Experience } & 0,0176 & 0,0208 & 0,0184 & 0,0181 \\
\hline & {$[10.10]^{3}$} & {$[9.41]^{3}$} & {$[9.71]^{3}$} & {$[11.05]^{3}$} \\
\hline \multirow[t]{2}{*}{ Experience squared } & $-0,0004$ & $-0,0004$ & $-0,0004$ & $-0,0003$ \\
\hline & {$[14.06]^{3}$} & {$[13.33]^{3}$} & {$[13.15]^{3}$} & {$[13.24]^{3}$} \\
\hline \multirow[t]{2}{*}{ Experience $\mathrm{x}$ schooling } & 0,0013 & 0,0015 & 0,001 & 0,0006 \\
\hline & {$[4.32]^{3}$} & {$[4.05]^{3}$} & {$[2.94]^{3}$} & {$[2.16]^{2}$} \\
\hline \multirow[t]{2}{*}{ Lower primary (D4) } & 0,1158 & 0,0354 & $-0,0335$ & $-0,034$ \\
\hline & {$[3.49]^{3}$} & {$[0.81]$} & {$[0.84]$} & {$[0.87]$} \\
\hline \multirow[t]{2}{*}{ Upper primary (D8) } & 0,1095 & 0,2018 & 0,1159 & 0,136 \\
\hline & {$[2.67]^{3}$} & {$[4.56]^{3}$} & {$[3.02]^{3}$} & {$[4.15]^{3}$} \\
\hline \multirow[t]{2}{*}{ Secondary school (D11) } & 0,3179 & 0,4054 & 0,3138 & 0,2718 \\
\hline & {$[6.70]^{3}$} & {$[8.27]^{3}$} & {$[7.75]^{3}$} & {$[8.39]^{3}$} \\
\hline \multirow[t]{2}{*}{ College (D15) } & 0,3106 & 0,2183 & 0,2176 & 0,192 \\
\hline & {$[6.52]^{3}$} & {$[3.64]^{3}$} & {$[3.93]^{3}$} & {$[4.29]^{3}$} \\
\hline \multirow[t]{2}{*}{ Experience x D4 } & 0 & 0,0017 & 0,0038 & 0,0032 \\
\hline & {$[0.03]$} & [1.14] & {$[2.85]^{3}$} & {$[2.48]^{2}$} \\
\hline \multirow{2}{*}{ Experience x D8 } & $-0,0022$ & $-0,0041$ & $-0,0024$ & $-0,0036$ \\
\hline & {$[1.29]$} & {$[2.16]^{2}$} & {$[1.50]$} & {$[2.77]^{3}$} \\
\hline \multirow[t]{2}{*}{ Experience x D11 } & $-0,0066$ & $-0,0118$ & $-0,007$ & $-0,0006$ \\
\hline & {$[3.78]^{3}$} & {$[6.49]^{3}$} & {$[4.75]^{3}$} & {$[0.55]$} \\
\hline \multirow[t]{2}{*}{ Experience x D15 } & $-0,0103$ & $-0,0085$ & $-0,0066$ & $-0,0068$ \\
\hline & {$[5.16]^{3}$} & {$[3.64]^{3}$} & {$[3.23]^{3}$} & {$[4.14]^{3}$} \\
\hline \multirow[t]{2}{*}{ Schooling $=16$} & 0,1565 & 0,0666 & $-0,0022$ & $-0,0418$ \\
\hline & {$[5.21]^{3}$} & {$[1.92]^{1}$} & {$[0.08]$} & {$[1.75]^{1}$} \\
\hline \multirow[t]{2}{*}{ D4 x (S-4) } & $-0,0019$ & $-0,0259$ & 0,0038 & $-0,0118$ \\
\hline & {$[0.26]$} & {$[3.08]^{3}$} & {$[0.52]$} & {$[1.77]^{1}$} \\
\hline \multirow[t]{2}{*}{ D8 $\times(S-8)$} & $-0,0058$ & 0,0316 & 0,0205 & $-0,0031$ \\
\hline & {$[0.40]$} & {$[2.28]^{2}$} & {$[1.87]^{1}$} & {$[0.33]$} \\
\hline \multirow[t]{2}{*}{ D11 x (S-11) } & 0,0418 & 0,0628 & 0,0873 & 0,1465 \\
\hline & {$[2.66]^{3}$} & {$[3.96]^{3}$} & {$[6.76]^{3}$} & {$[14.01]^{3}$} \\
\hline \multirow[t]{2}{*}{ D15 x (S-15) } & $-0,0628$ & 0,0203 & 0,0727 & 0,0954 \\
\hline & {$[2.66]^{3}$} & {$[0.87]$} & {$[3.64]^{3}$} & {$[6.09]^{3}$} \\
\hline Woman & $-0,8701$ & $-0,7234$ & $-0,6327$ & $-0,5966$ \\
\hline & {$[120.96]^{3}$} & {$[95.16]^{3}$} & {$[101.62]^{3}$} & {$[111.51]^{3}$} \\
\hline Black & $-0,1493$ & $-0,1557$ & $-0,1517$ & $-0,1601$ \\
\hline & {$[22.22]^{3}$} & {$[19.94]^{3}$} & {$[22.79]^{3}$} & {$[28.32]^{3}$} \\
\hline Northeast & $-0,3403$ & $-0,2398$ & $-0,2568$ & $-0,3103$ \\
\hline & {$[29.82]^{3}$} & {$[16.17]^{3}$} & {$[20.41]^{3}$} & {$[34.44]^{3}$} \\
\hline Southeast & $-0,0238$ & 0,2348 & 0,2173 & 0,1423 \\
\hline & {$[2.29]^{2}$} & {$[17.36]^{3}$} & {$[18.09]^{3}$} & {$[17.23]^{3}$} \\
\hline South & $-0,1074$ & 0,1221 & 0,0982 & 0,0726 \\
\hline & {$[8.96]^{3}$} & {$[8.08]^{3}$} & {$[7.39]^{3}$} & {$[7.56]^{3}$} \\
\hline Center-west & $-0,1087$ & 0,0703 & 0,0882 & 0,1437 \\
\hline & {$[9.10]^{3}$} & {$[4.58]^{3}$} & {$[6.48]^{3}$} & {$[14.79]^{3}$} \\
\hline Constant & 5,7142 & 5,1527 & 5,442 & 5,1679 \\
\hline & {$[185.57]^{3}$} & {$[124.77]^{3}$} & {$[150.83]^{3}$} & {$[163.33]^{3}$} \\
\hline F-test for sheepskin effects $=0$ & 20,87 & 25,600 & 25,530 & 29,900 \\
\hline Prob $>F$ & 0,000 & 0,000 & 0,000 & 0,000 \\
\hline F-test for splines $=0$ & 4,51 & 21,680 & 55,030 & 147,180 \\
\hline Prob $>F$ & 0,001 & 0,000 & 0,000 & 0,000 \\
\hline Observations & 71366 & 55542 & 63920 & 83988 \\
\hline R-squared & 0,54 & 0,46 & 0,50 & 0,48 \\
\hline
\end{tabular}

${ }^{a}$ Note: Robust t-statistics in brackets.

${ }^{1}$ Significant at $10 \%$.

2 Significant at $5 \%$.

${ }^{3}$ Significant at $1 \%$. 
Table 3: Earnings equation - semiparametric approach

\begin{tabular}{|c|c|c|c|c|}
\hline \multicolumn{5}{|c|}{ Dependent variable: log of earnings in the main job } \\
\hline & 1982 & 1992 & 1998 & 2004 \\
\hline & (1) & (2) & (3) & (4) \\
\hline \multirow[t]{2}{*}{ Years of schooling $=1$} & 0,1301 & 0,1072 & 0,0529 & 0,0519 \\
\hline & {$[7.88]^{3}$} & {$[4.49]^{3}$} & {$[2.39]^{2}$} & {$[2.48]^{2}$} \\
\hline \multirow[t]{2}{*}{ Years of schooling $=2$} & 0,2125 & 0,1891 & 0,1115 & 0,1035 \\
\hline & {$[15.10]^{3}$} & {$[10.02]^{3}$} & {$[6.59]^{3}$} & {$[6.07]^{3}$} \\
\hline \multirow[t]{2}{*}{ Years of schooling $=3$} & 0,2915 & 0,2552 & 0,1824 & 0,1632 \\
\hline & {$[20.42]^{3}$} & {$[14.14]^{3}$} & {$[11.56]^{3}$} & {$[10.57]^{3}$} \\
\hline \multirow[t]{2}{*}{ Years of schooling $=4$} & 0,5085 & 0,4349 & 0,3123 & 0,2778 \\
\hline & {$[37.02]^{3}$} & {$[25.96]^{3}$} & {$[20.99]^{3}$} & {$[20.08]^{3}$} \\
\hline \multirow[t]{2}{*}{ Years of schooling $=5$} & 0,5706 & 0,4329 & 0,3388 & 0,2903 \\
\hline & {$[23.61]^{3}$} & {$[18.63]^{3}$} & {$[18.04]^{3}$} & {$[17.43]^{3}$} \\
\hline \multirow[t]{2}{*}{ Years of schooling $=6$} & 0,6823 & 0,522 & 0,4106 & 0,3386 \\
\hline & {$[27.23]^{3}$} & {$[20.85]^{3}$} & {$[19.63]^{3}$} & {$[18.18]^{3}$} \\
\hline \multirow[t]{2}{*}{ Years of schooling $=7$} & 0,7559 & 0,5611 & 0,475 & 0,3865 \\
\hline & {$[30.33]^{3}$} & {$[21.70]^{3}$} & {$[21.90]^{3}$} & {$[19.97]^{3}$} \\
\hline \multirow[t]{2}{*}{ Years of schooling $=8$} & 0,915 & 0,7362 & 0,5921 & 0,4776 \\
\hline & {$[41.75]^{3}$} & {$[30.39]^{3}$} & {$[28.58]^{3}$} & {$[25.81]^{3}$} \\
\hline \multirow[t]{2}{*}{ Years of schooling $=9$} & 0,9472 & 0,7818 & 0,6662 & 0,4693 \\
\hline & {$[27.02]^{3}$} & {$[23.28]^{3}$} & {$[24.44]^{3}$} & {$[20.10]^{3}$} \\
\hline \multirow[t]{2}{*}{ Years of schooling $=10$} & 1,0682 & 0,8801 & 0,711 & 0,5657 \\
\hline & {$[32.68]^{3}$} & {$[26.79]^{3}$} & {$[25.87]^{3}$} & {$[23.41]^{3}$} \\
\hline \multirow[t]{2}{*}{ Years of schooling $=11$} & 1,3302 & 1,1038 & 0,9561 & 0,822 \\
\hline & {$[53.74]^{3}$} & {$[39.75]^{3}$} & {$[40.31]^{3}$} & {$[39.03]^{3}$} \\
\hline \multirow[t]{2}{*}{ Years of schooling $=12$} & 1,4876 & 1,3573 & 1,2468 & 1,1951 \\
\hline & {$[35.31]^{3}$} & {$[29.54]^{3}$} & {$[29.41]^{3}$} & {$[39.63]^{3}$} \\
\hline \multirow[t]{2}{*}{ Years of schooling $=13$} & 1,5162 & 1,4577 & 1,2853 & 1,1958 \\
\hline & {$[38.18]^{3}$} & {$[33.54]^{3}$} & {$[34.05]^{3}$} & {$[40.53]^{3}$} \\
\hline \multirow[t]{2}{*}{ Years of schooling $=14$} & 1,703 & 1,4713 & 1,4087 & 1,2784 \\
\hline & {$[47.16]^{3}$} & {$[35.32]^{3}$} & {$[38.96]^{3}$} & {$[41.50]^{3}$} \\
\hline \multirow[t]{2}{*}{ Years of schooling $=15$} & 1,9269 & 1,7222 & 1,6785 & 1,5781 \\
\hline & {$[61.22]^{3}$} & {$[48.05]^{3}$} & {$[53.56]^{3}$} & {$[57.59]^{3}$} \\
\hline \multirow[t]{2}{*}{ Years of schooling $=16$} & 2,1381 & 1,9483 & 1,9191 & 1,8144 \\
\hline & {$[59.89]^{3}$} & {$[45.37]^{3}$} & {$[53.46]^{3}$} & {$[57.40]^{3}$} \\
\hline \multirow[t]{2}{*}{ Years of schooling $=17$} & 2,055 & 2,0709 & 2,1716 & 2,1575 \\
\hline & {$[39.46]^{3}$} & {$[38.90]^{3}$} & {$[48.76]^{3}$} & {$[57.61]^{3}$} \\
\hline \multirow[t]{2}{*}{ Constant } & 5,609 & 4,9041 & 5,2281 & 5,0254 \\
\hline & {$[201.85]^{3}$} & {$[149.41]^{3}$} & {$[185.03]^{3}$} & {$[202.03]^{3}$} \\
\hline Observations & 71366 & 64342 & 74335 & 98414 \\
\hline R-squared & 0,54 & 0,44 & 0,48 & 0,46 \\
\hline
\end{tabular}

Note: Robust t-statistics in brackets.

Regressions control for potencial experience, potencial experience squared, gender, race, region and years of schooling $\mathrm{x}$ potencial experience.

1 significant at $10 \%$.

2 significant at $5 \%$.

3 significant at $1 \%$. 
Table 4: Earnings equation

\begin{tabular}{|c|c|c|c|c|c|c|c|c|}
\hline \multicolumn{9}{|c|}{ Dependent variable: log of earnings in the main job } \\
\hline & \multicolumn{4}{|c|}{ Northeast } & \multicolumn{4}{|c|}{ Southeast } \\
\hline & 1982 & 1992 & 1998 & 2004 & 1982 & 1992 & 1998 & 2004 \\
\hline & (1) & (2) & (3) & (4) & (5) & (6) & (7) & (8) \\
\hline \multirow[t]{2}{*}{ Years of schooling (S) } & 0,0823 & 0,0668 & 0,0647 & 0,0561 & 0,0488 & 0,0441 & 0,0063 & 0,0163 \\
\hline & {$[4.10]^{3}$} & {$[2.54]^{2}$} & {$[3.10]^{3}$} & {$[2.88]^{3}$} & {$[3.47]^{3}$} & {$[2.32]^{2}$} & {$[0.36]$} & {$[1.03]$} \\
\hline \multirow[t]{2}{*}{ Experience } & 0,0091 & 0,0173 & 0,0215 & 0,0136 & 0,0216 & 0,023 & 0,0182 & 0,0196 \\
\hline & {$[2.47]^{2}$} & {$[3.71]^{3}$} & {$[5.82]^{3}$} & {$[4.05]^{3}$} & {$[8.17]^{3}$} & {$[6.71]^{3}$} & {$[5.94]^{3}$} & {$[7.35]^{3}$} \\
\hline \multirow[t]{2}{*}{ Experience squared } & $-0,0002$ & $-0,0004$ & $-0,0004$ & $-0,0003$ & $-0,0005$ & $-0,0005$ & $-0,0004$ & $-0,0004$ \\
\hline & {$[4.18]^{3}$} & {$[4.71]^{3}$} & {$[7.05]^{3}$} & {$[4.97]^{3}$} & {$[11.41]^{3}$} & {$[10.13]^{3}$} & {$[8.79]^{3}$} & {$[9.23]^{3}$} \\
\hline \multirow[t]{2}{*}{ Experience $\mathrm{x}$ schooling } & 0,0014 & 0,0012 & 0,0006 & 0,001 & 0,0015 & 0,0012 & 0,0011 & 0,0005 \\
\hline & {$[1.99]^{2}$} & {$[1.33]$} & [0.92] & {$[1.68]^{*}$} & {$[3.26]^{3}$} & {$[2.17]^{2}$} & {$[2.10]^{2}$} & {$[1.03]$} \\
\hline \multirow[t]{2}{*}{ Lower primary (D4) } & 0,1339 & 0,0244 & 0,0129 & 0,009 & 0,1259 & $-0,0255$ & $-0,0429$ & $-0,0338$ \\
\hline & {$[1.72]^{1}$} & {$[0.22]$} & {$[0.15]$} & {$[0.11]$} & {$[2.62]^{3}$} & {$[0.39]$} & {$[0.69]$} & {$[0.54]$} \\
\hline \multirow[t]{2}{*}{ Upper primary (D8) } & $-0,1467$ & 0,2977 & 0,0941 & 0,0217 & 0,2129 & 0,1222 & 0,1284 & 0,1447 \\
\hline & [1.49] & {$[2.85]^{3}$} & [1.14] & {$[0.30]$} & {$[3.54]^{3}$} & {$[1.81]^{1}$} & {$[2.13]^{2}$} & {$[2.78]^{3}$} \\
\hline \multirow[t]{2}{*}{ Secondary school (D11) } & 0,4276 & 0,4712 & 0,27 & 0,3389 & 0,2694 & 0,33 & 0,3076 & 0,2722 \\
\hline & {$[3.81]^{3}$} & {$[4.15]^{3}$} & {$[3.27]^{3}$} & {$[4.88]^{3}$} & {$[3.76]^{3}$} & {$[4.25]^{3}$} & {$[4.67]^{3}$} & {$[5.16]^{3}$} \\
\hline \multirow[t]{2}{*}{ College (D15) } & 0,1138 & $-0,0083$ & 0,2673 & 0,1664 & 0,3392 & 0,2512 & 0,1585 & 0,1869 \\
\hline & {$[0.97]$} & {$[0.05]$} & {$[2.10]^{2}$} & {$[1.71]^{1}$} & {$[4.93]^{3}$} & {$[2.80]^{3}$} & {$[1.91]^{1}$} & {$[2.61]^{3}$} \\
\hline \multirow[t]{2}{*}{ Experience x D4 } & $-0,0025$ & 0,004 & 0,0016 & 0,0006 & 0,001 & 0,0038 & 0,0052 & 0,0048 \\
\hline & {$[0.84]$} & [1.03] & {$[0.52]$} & {$[0.22]$} & {$[0.57]$} & {$[1.77]^{1}$} & {$[2.52]^{2}$} & {$[2.40]^{2}$} \\
\hline \multirow[t]{2}{*}{ Experience x D8 } & 0,0062 & $-0,0056$ & $-0,0016$ & $-0,0024$ & $-0,0055$ & $-0,0022$ & $-0,0037$ & $-0,0038$ \\
\hline & {$[1.53]$} & {$[1.25]$} & {$[0.47]$} & {$[0.80]$} & {$[2.24]^{2}$} & {$[0.77]$} & [1.47] & {$[1.87]^{1}$} \\
\hline \multirow[t]{2}{*}{ Experience $\mathrm{x}$ D11 } & $-0,0119$ & $-0,0063$ & $-0,0018$ & $-0,0008$ & $-0,0049$ & $-0,0116$ & $-0,0076$ & $-0,0008$ \\
\hline & {$[2.94]^{3}$} & [1.53] & {$[0.61]$} & {$[0.32]$} & {$[1.94]^{1}$} & {$[4.16]^{3}$} & {$[3.18]^{3}$} & {$[0.45]$} \\
\hline \multirow[t]{2}{*}{ Experience $\mathrm{x}$ D15 } & $-0,0108$ & $-0,0083$ & $-0,006$ & $-0,0099$ & $-0,0114$ & $-0,0091$ & $-0,0052$ & $-0,005$ \\
\hline & {$[2.30]^{2}$} & {$[1.51]$} & {$[1.34]$} & {$[2.66]^{3}$} & {$[4.09]^{3}$} & {$[2.65]^{3}$} & {$[1.65]^{1}$} & {$[1.97]^{2}$} \\
\hline \multirow[t]{2}{*}{ Schooling $=16$} & 0,1692 & 0,0177 & 0,0474 & 0,1496 & 0,1887 & 0,0895 & 0,0091 & $-0,0984$ \\
\hline & {$[2.46]^{2}$} & {$[0.22]$} & [0.72] & {$[2.69]^{3}$} & {$[4.31]^{3}$} & {$[1.73]^{1}$} & {$[0.22]$} & {$[2.70]^{3}$} \\
\hline \multirow[t]{2}{*}{ D4 x (S-4) } & $-0,0115$ & $-0,0517$ & $-0,0197$ & 0,0005 & 0,0091 & $-0,0106$ & 0,0387 & 0,0218 \\
\hline & {$[0.67]$} & {$[2.56]^{2}$} & [1.29] & {$[0.03]$} & [0.88] & {$[0.83]$} & {$[3.35]^{3}$} & {$[2.05]^{2}$} \\
\hline \multirow[t]{2}{*}{ D8 $x(\mathrm{~S}-8)$} & 0,0037 & 0,0062 & 0,0288 & $-0,0285$ & $-0,0047$ & 0,0339 & 0,0087 & $-0,0051$ \\
\hline & {$[0.10]$} & {$[0.17]$} & [1.13] & [1.35] & [0.22] & [1.59] & {$[0.51]$} & {$[0.34]$} \\
\hline \multirow[t]{2}{*}{ D11 $x(S-11)$} & 0,1224 & 0,1907 & 0,0961 & 0,186 & 0,0264 & 0,0497 & 0,0992 & 0,1383 \\
\hline & {$[3.09]^{3}$} & {$[4.41]^{3}$} & {$[2.99]^{3}$} & {$[7.89]^{3}$} & [1.14] & {$[2.06]^{2}$} & {$[5.10]^{3}$} & {$[8.37]^{3}$} \\
\hline \multirow[t]{2}{*}{ D15 $x(S-15)$} & $-0,1139$ & $-0,045$ & 0,0748 & 0,0487 & $-0,0633$ & 0,0104 & 0,0751 & 0,1028 \\
\hline & {$[2.07]^{2}$} & {$[0.79]$} & {$[1.67]^{*}$} & [1.27] & {$[1.79]^{1}$} & {$[0.31]$} & {$[2.58]^{3}$} & {$[4.39]^{3}$} \\
\hline Woman & $-0,9434$ & $-0,7884$ & $-0,6397$ & $-0,6045$ & $-0,8758$ & $-0,7199$ & $-0,626$ & $-0,6025$ \\
\hline & {$[57.08]^{3}$} & {$[43.31]^{3}$} & {$[48.47]^{3}$} & {$[50.01]^{3}$} & {$[84.46]^{3}$} & {$[64.26]^{3}$} & {$[64.86]^{3}$} & {$[72.22]^{3}$} \\
\hline Black & $-0,0808$ & $-0,1278$ & $-0,1085$ & $-0,125$ & $-0,1806$ & $-0,1744$ & $-0,1744$ & $-0,1832$ \\
\hline & {$[5.38]^{3}$} & {$[6.97]^{3}$} & {$[7.54]^{3}$} & {$[9.94]^{3}$} & {$[19.12]^{3}$} & {$[15.92]^{3}$} & {$[18.00]^{3}$} & {$[21.89]^{3}$} \\
\hline Constant & 5,4246 & 4,8625 & 5,0393 & 4,7956 & 5,6883 & 5,4416 & 5,7818 & 5,4132 \\
\hline & {$[92.16]^{3}$} & {$[64.27]^{3}$} & {$[81.68]^{3}$} & {$[81.76]^{3}$} & {$[123.78]^{3}$} & {$[85.29]^{3}$} & {$[99.99]^{3}$} & {$[101.94]^{3}$} \\
\hline F-test for sheepskin effects $=0$ & 4,920 & 6,860 & 4,230 & 7,330 & 10,220 & 8,460 & 9,350 & 11,330 \\
\hline Prob $>$ F & 0,001 & 0,000 & 0,002 & 0,000 & 0,000 & 0,000 & 0,000 & 0,000 \\
\hline F-test for splines $=0$ & 6,620 & 11,030 & 11,040 & 30,920 & 1,640 & 8,210 & 34,120 & 65,370 \\
\hline Prob $>$ F & 0,000 & 0,000 & 0,000 & 0,000 & 0,162 & 0,000 & 0,000 & 0,000 \\
\hline Observations & 15402 & 13361 & 16512 & 22391 & 27592 & 21051 & 22809 & 26957 \\
\hline R-squared & 0,50 & 0,4 & 0,44 & 0,41 & 0,53 & 0,44 & 0,47 & 0,47 \\
\hline
\end{tabular}

Note: Robust t-statistics in brackets.

1 significant at $10 \%$.

2 significant at $5 \%$.

3 significant at $1 \%$. 
thereafter. The same pattern is verified for upper primary education in the Southeast. The coefficient associated with secondary school decreased in the Northeast and remained almost constant in the Southeast. The college degree coefficient was nonsignificant in 1982 and 1992 in the Northeast and became positive and significant in 1998 and 2004. In the Southeast, the extra earnings gain associated with the completion of college present a decreasing trend, but they were still very high in 2004 (19\%). Ftests show that the sheepskin effect coefficients were significantly different from zero in all regressions reported. It is possible to notice in Table 4 that each additional year of schooling has a stronger impact on the log of earnings in the Northeast than in the Southeast. These linear effects decreased from 1982 to 2004 in both regions.

According to Table 4, a positive trend over time is verified for the spline associated with college degree only for the Southeast, while spline functions related to secondary school present an increasing trend in both regions. F-tests for spline functions are significant in all cases, except for the Southeast in 1982. These changes in spline functions imply a growing convexity of the log of the earningsschooling relationship, which is more dramatic for the Southeast, as shown in Figure A-2. Evidence from semiparametric regressions is presented in Figure A-3. Returns to schooling seem to be an even more convex function of years of education using this specification.

Evidence provided by Lemieux (2006) shows that since the 1980s log earnings have become an increasingly convex function of years of schooling in the United States. According to Autor et al. (2006), these changes could be explained by the intensive use of computers, which complements non-routine and more complex tasks of highly educated workers and substitutes the routine tasks performed by workers in the middle of the educational distribution. Computers may have lower consequences for non-routine manual tasks of less educated individuals. Our evidence reported in Figure A-2 is consistent with the argument of Autor et al. (2006). The reduction in mean labor earnings from 1982 to 2004 was much more intense for middle-educated workers with years of schooling between 4 and 10, mainly in the Southeast, when compared to the Northeast.

The Appendix reports evidence for the other three Brazilian regions. In each one of these cases sheepskin effects also present a negative trend over time. In addition, it is possible to notice that spline functions for high degrees have the same positive trend verified for the whole country. Growing convexity in the log of the earnings-education relationship was identified for the South and the Center West in Figure A-2, which uses splines and discontinuous functions, as well as for the former region in Figure A-3 using dummies for years of schooling.

\section{CONCLUSION}

This paper is concerned with analyzing the evolution of sheepskin effects in Brazil from 1982 to 2004. During this period, a lot of changes occurred in the Brazilian labor market, which could be connected with alterations in the relationship between earnings and schooling. On the one hand, there was a substantial increase in the supply of more educated individuals. On the other hand, firms increased the necessity of hiring high skilled workers as they adopted new technologies, especially after the 1990s.

The results estimated using PNAD data show that sheepskin effects changed considerably during the period analyzed, as well as did the relationship between education and log earnings. From 1982 to 2004, the sheepskin effect basically disappeared for the first degree (lower primary school), and decreased for secondary and college degrees. This evidence is consistent with the higher supply of more educated workers in the labor force reducing the importance of higher degrees as a signal of more productive workers. However, estimated earnings gains associated with the completion of these degrees were still elevated in 2004.

For higher degrees, spline functions have a positive trend, indicating that the convexity patterns of returns to education were exacerbated over time. From 1982 to 2004, the reduction in mean earnings 
was more dramatic for middle-educated workers, who had between 4 and 10 years of completed schooling. For those with very low educational level or with more than 12 years of schooling the reductions in earnings were not so strong.

The results by region show that growing convexity of the relationship between the log of earnings and education were more intense in the Southeast, South and Center West. In addition, we found reductions in the sheepskin effects over time in each one of the Brazilian regions separately.

\section{BIBLIOGRAPHY}

Autor, D., Katz, L., \& Kearney, M. (2006). The polarization of the U.S. labor market. mimeo.

Autor, D., Katz, L., \& Krueger, A. (1998). Computing inequality: Have computers changed the labor market? Quarterly Journal of Economics, 113(4).

Belman, D. \& Heywood, J. (1991). Sheepskin effects in return to education: An examination of women and minorities. Review of Economics and Statistics, 73:720-724.

Belman, D. \& Heywood, J. (1997). Sheepskin effects by Cohorts: Implications of job matching in a signaling model. Oxford Economic Papers, 49(4):623-637.

Berman, E., Bound, J., \& Griliches, Z. (1994). Changes in the demand for skilled labor within U. S. manufacturing industries: Evidence from the annual survey of manufactures. Quarterly Journal of Economics, 109(2).

Card, D. (1999). The casual effect of education on earnings. In Ashenfelter, O. \& Card, D., editors, Handbook of Labor Economics, Vol.

Deschênes, O. (2006). Unobserved ability, comparative advantage, and the rising return to education in the United States 1979-2002. mimeo.

Fernandes, R. \& Menezes-Filho, N. (2002). Escolaridade e demanda relativa por trabalho. In O Mercado de Trabalho No Brasil. LTR, São Paulo. Menezes-Filho, N. \& Chahad, J.

Ferrer, A. \& Riddell, W. (2002). The role credentials in the Canadian labour market. Canadian Journal of Economics, 35(4).

Hungerford, T. \& Solon, G. (1987). Sheepskin effects in the return to education. Review of Economics and Statistics, 69:175-177.

Jaeger, D. \& Page, M. (1996). Degrees matter: New evidence on the sheepskin effects in the return to education. Review of Economics and Statistics, 78:733-740.

Lam, D. \& Schoeni, R. (1993). Effects of family background on earnings and returns to schooling: Evidence from Brazil. Journal of Political Economy, 101(4).

Lemieux, T. (2006). The mincer equation thirty years after schooling, experience, and earnings. In Grossbard-Shechtman, S. \& Jacob Mincer, A., editors, A Pioneer of Modern Labor Economics. Springer Verlag.

Menezes-Filho, N. \& Rodrigues, M. (2003). Tecnologia e demanda por qualificação na indústria brasileira. Revista Brasileira de Economia, 57(3).

Mincer, J. (1974). Schooling, Experience and Earnings. Columbia University Press, New York. 
Park, J. H. (1999). Estimation of sheepskin effects using the old and the new measures of educational attainment in the current population survey. Economics Letters, 62:237-240.

Pons, E. (2006). Diploma effects by gender in the spanish labour market. Labour, 20(1).

Ramos, L. \& Vieira, M. L. (1996). A relaçao entre educaçao e salários no Brasil. Texto para discussão do IPEA 21/96.

Schady, N. (2003). Convexity and sheepskin effects in the human capital earnings function: Recent evidence for Filipino men. mimeo.

Weiss, A. (1995). Human capital vs. signalling explanations of wages. Journal of Economic Perspectives, $9(4)$.

\section{A. TABLES}


Table A-1: Earnings equation

\begin{tabular}{|c|c|c|c|c|}
\hline \multicolumn{5}{|c|}{ Dependent variable: log of hourly earnings in the main job } \\
\hline & 1982 & 1992 & 1998 & 2004 \\
\hline & (1) & (2) & (3) & (4) \\
\hline \multirow[t]{2}{*}{ Years of schooling (S) } & 0,0642 & 0,0566 & 0,0327 & 0,053 \\
\hline & {$[7.20]^{3}$} & {$[4.86]^{3}$} & {$[3.04]^{3}$} & {$[5.67]^{3}$} \\
\hline \multirow[t]{2}{*}{ Experience } & 0,0107 & 0,0148 & 0,0142 & 0,0133 \\
\hline & {$[6.59]^{3}$} & {$[6.85]^{3}$} & {$[7.37]^{3}$} & {$[8.18]^{3}$} \\
\hline \multirow[t]{2}{*}{ Experience squared } & $-0,0002$ & $-0,0003$ & $-0,0003$ & $-0,0002$ \\
\hline & {$[9.65]^{3}$} & {$[9.57]^{3}$} & {$[9.27]^{3}$} & {$[8.60]^{3}$} \\
\hline \multirow[t]{2}{*}{ Experience $\mathrm{x}$ schooling } & 0,0013 & 0,0012 & 0,001 & 0,0003 \\
\hline & {$[4.39]^{3}$} & {$[3.34]^{3}$} & {$[3.07]^{3}$} & [0.99] \\
\hline \multirow[t]{2}{*}{ Lower primary (D4) } & 0,084 & $-0,0291$ & $-0,0106$ & $-0,0938$ \\
\hline & {$[2.67]^{3}$} & {$[0.70]$} & {$[0.26]$} & {$[2.48]^{2}$} \\
\hline \multirow[t]{2}{*}{ Upper primary (D8) } & 0,0641 & 0,1419 & 0,1145 & 0,0927 \\
\hline & {$[1.61]$} & {$[3.26]^{3}$} & {$[2.95]^{3}$} & {$[2.87]^{3}$} \\
\hline \multirow[t]{2}{*}{ Secondary school (D11) } & 0,3657 & 0,4073 & 0,3543 & 0,2249 \\
\hline & {$[7.73]^{3}$} & {$[8.38]^{3}$} & {$[8.63]^{3}$} & {$[7.04]^{3}$} \\
\hline \multirow[t]{2}{*}{ College (D15) } & 0,254 & 0,1639 & 0,1601 & 0,1735 \\
\hline & {$[5.58]^{3}$} & {$[2.79]^{3}$} & {$[2.88]^{3}$} & {$[3.94]^{3}$} \\
\hline \multirow{2}{*}{ Experience x D4 } & 0,0014 & 0,0036 & 0,0029 & 0,0047 \\
\hline & {$[1.27]$} & {$[2.52]^{2}$} & {$[2.14]^{2}$} & {$[3.81]^{3}$} \\
\hline \multirow{2}{*}{ Experience x D8 } & $-0,0001$ & $-0,0017$ & $-0,002$ & $-0,0019$ \\
\hline & {$[0.06]$} & {$[0.92]$} & {$[1.22]$} & {$[1.52]$} \\
\hline \multirow[t]{2}{*}{ Experience x D11 } & $-0,0078$ & $-0,012$ & $-0,0073$ & 0,0016 \\
\hline & {$[4.49]^{3}$} & {$[6.57]^{3}$} & {$[4.84]^{3}$} & [1.39] \\
\hline \multirow[t]{2}{*}{ Experience x D15 } & $-0,0094$ & $-0,0071$ & $-0,0059$ & $-0,0073$ \\
\hline & {$[4.83]^{3}$} & {$[3.11]^{3}$} & {$[2.90]^{3}$} & {$[4.49]^{3}$} \\
\hline \multirow[t]{2}{*}{ Schooling $=16$} & 0,1194 & 0,0686 & $-0,0324$ & $-0,0593$ \\
\hline & {$[4.42]^{3}$} & {$[2.05]^{2}$} & {$[1.15]$} & {$[2.60]^{3}$} \\
\hline \multirow[t]{2}{*}{ D4 x (S-4) } & 0,0097 & $-0,0223$ & 0,008 & $-0,0079$ \\
\hline & [1.36] & {$[2.70]^{3}$} & [1.11] & {$[1.22]$} \\
\hline \multirow[t]{2}{*}{ D8 $x(S-8)$} & $-0,0032$ & 0,0435 & 0,0204 & $-0,0054$ \\
\hline & {$[0.22]$} & {$[3.15]^{3}$} & {$[1.81]^{1}$} & [0.59] \\
\hline \multirow[t]{2}{*}{ D11 $x(S-11)$} & 0,0541 & 0,0632 & 0,1166 & 0,1756 \\
\hline & {$[3.45]^{3}$} & {$[4.01]^{3}$} & {$[8.94]^{3}$} & {$[16.85]^{3}$} \\
\hline \multirow[t]{2}{*}{ D15 x (S-15) } & $-0,0087$ & 0,0186 & 0,0602 & 0,0853 \\
\hline & {$[0.42]$} & [0.79] & {$[2.93]^{3}$} & {$[5.76]^{3}$} \\
\hline Woman & $-0,5306$ & $-0,4428$ & $-0,3641$ & $-0,3393$ \\
\hline & {$[81.53]^{3}$} & {$[60.72]^{3}$} & {$[58.31]^{3}$} & {$[64.45]^{3}$} \\
\hline Black & $-0,1535$ & $-0,1544$ & $-0,1508$ & $-0,1432$ \\
\hline & {$[23.74]^{3}$} & {$[20.01]^{3}$} & {$[22.33]^{3}$} & {$[25.33]^{3}$} \\
\hline Northeast & $-0,2864$ & $-0,2049$ & $-0,1946$ & $-0,2693$ \\
\hline & {$[25.82]^{3}$} & {$[13.68]^{3}$} & {$[15.19]^{3}$} & {$[29.46]^{3}$} \\
\hline Southeast & $-0,0004$ & 0,225 & 0,2321 & 0,1272 \\
\hline & [0.04] & {$[16.34]^{3}$} & {$[18.92]^{3}$} & {$[15.09]^{3}$} \\
\hline South & $-0,1113$ & 0,1156 & 0,1128 & 0,0648 \\
\hline & {$[9.52]^{3}$} & {$[7.60]^{3}$} & {$[8.39]^{3}$} & {$[6.70]^{3}$} \\
\hline Center & $-0,1079$ & 0,0559 & 0,0763 & 0,1122 \\
\hline & {$[9.20]^{3}$} & {$[3.56]^{3}$} & {$[5.44]^{3}$} & {$[11.26]^{3}$} \\
\hline Constant & 1,8852 & 1,3806 & 1,6479 & 1,4381 \\
\hline & {$[65.52]^{3}$} & {$[34.16]^{3}$} & {$[44.79]^{3}$} & {$[45.98]^{3}$} \\
\hline F-test for sheepskin effects $=0$ & 22,150 & 26,590 & 25,760 & 27,650 \\
\hline Prob $>F$ & 0,000 & 0,000 & 0,000 & 0,000 \\
\hline F-test for splines $=0$ & 11,700 & 28,290 & 82,780 & 203,810 \\
\hline Prob $>F$ & 0,000 & 0,000 & 0,000 & 0,000 \\
\hline Observations & 71366 & 55520 & 63862 & 83949 \\
\hline R-squared & 0,54 & 0,44 & 0,47 & 0,46 \\
\hline
\end{tabular}

${ }^{a}$ Note: Robust t-statistics in brackets.

${ }^{1}$ significant at $10 \%$.

2 significant at $5 \%$.

${ }^{3}$ significant at $1 \%$. 
Table A-2: Earnings equation

\begin{tabular}{|c|c|c|c|c|c|c|c|c|}
\hline \multicolumn{9}{|c|}{ Dependent variable: log of hourly earnings in the main job } \\
\hline & \multicolumn{4}{|c|}{ Northeast } & \multicolumn{4}{|c|}{ Southeast } \\
\hline & 1982 & 1992 & 1998 & 2004 & 1982 & 1992 & 1998 & 2004 \\
\hline & (1) & (2) & (3) & (4) & (5) & (6) & (7) & (8) \\
\hline \multirow[t]{2}{*}{ Years of schooling $(\mathrm{S})$} & 0,0796 & 0,0798 & 0,0617 & 0,047 & 0,0509 & 0,0511 & 0,0048 & 0,0262 \\
\hline & {$[4.13]^{3}$} & {$[3.08]^{3}$} & {$[3.04]^{3}$} & {$[2.55]^{2}$} & {$[3.80]^{3}$} & {$[2.85]^{3}$} & {$[0.27]$} & {$[1.68]^{1}$} \\
\hline \multirow[t]{2}{*}{ Experience } & 0,0074 & 0,0117 & 0,0202 & 0,0079 & 0,0122 & 0,0167 & 0,014 & 0,0154 \\
\hline & {$[2.10]^{2}$} & {$[2.52]^{2}$} & {$[5.64]^{3}$} & {$[2.33]^{2}$} & {$[4.99]^{3}$} & {$[5.02]^{3}$} & {$[4.47]^{3}$} & {$[5.73]^{3}$} \\
\hline \multirow[t]{2}{*}{ Experience squared } & $-0,0002$ & $-0,0002$ & $-0,0003$ & $-0,0001$ & $-0,0003$ & $-0,0004$ & $-0,0003$ & $-0,0002$ \\
\hline & {$[3.46]^{3}$} & {$[2.86]^{3}$} & {$[6.11]^{3}$} & {$[2.57]^{2}$} & {$[7.35]^{3}$} & {$[7.68]^{3}$} & {$[6.31]^{3}$} & {$[6.33]^{3}$} \\
\hline \multirow[t]{2}{*}{ Experience $\mathrm{x}$ schooling } & 0,0015 & 0,0004 & 0,0006 & 0,0011 & 0,0014 & 0,0011 & 0,0011 & 0,0001 \\
\hline & {$[2.20]^{2}$} & {$[0.46]$} & {$[0.83]$} & {$[1.95]^{1}$} & {$[3.16]^{3}$} & {$[2.05]^{2}$} & {$[2.13]^{2}$} & {$[0.12]$} \\
\hline \multirow[t]{2}{*}{ Lower primary (D4) } & 0,1498 & $-0,0723$ & 0,0177 & 0,0121 & 0,0885 & $-0,0913$ & $-0,0244$ & $-0,1134$ \\
\hline & {$[2.04]^{2}$} & {$[0.67]$} & {$[0.21]$} & {$[0.15]$} & {$[1.93]^{1}$} & {$[1.53]$} & {$[0.39]$} & {$[1.87]^{1}$} \\
\hline \multirow[t]{2}{*}{ Upper primary (D8) } & $-0,1283$ & 0,1892 & 0,1062 & 0,0351 & 0,137 & 0,0666 & 0,0991 & 0,1379 \\
\hline & {$[1.34]$} & {$[1.88]^{1}$} & {$[1.30]$} & {$[0.50]$} & {$[2.36]^{2}$} & {$[1.00]$} & {$[1.64]$} & {$[2.66]^{3}$} \\
\hline \multirow[t]{2}{*}{ Secondary school (D11) } & 0,4616 & 0,479 & 0,295 & 0,3219 & 0,318 & 0,3494 & 0,3632 & 0,1943 \\
\hline & {$[4.32]^{3}$} & {$[4.43]^{3}$} & {$[3.58]^{3}$} & {$[4.60]^{3}$} & {$[4.40]^{3}$} & {$[4.57]^{3}$} & {$[5.44]^{3}$} & {$[3.77]^{3}$} \\
\hline \multirow[t]{2}{*}{ College (D15) } & 0,1299 & $-0,1736$ & 0,1401 & 0,1593 & 0,2543 & 0,2137 & 0,1299 & 0,195 \\
\hline & {$[1.18]$} & {$[1.18]$} & {$[1.12]$} & {$[1.67]^{1}$} & {$[3.87]^{3}$} & {$[2.42]^{2}$} & [1.53] & {$[2.74]^{3}$} \\
\hline \multirow[t]{2}{*}{ Experience $\mathrm{x}$ D4 } & $-0,0031$ & 0,0075 & 0,001 & 0,0005 & 0,0026 & 0,0054 & 0,004 & 0,0071 \\
\hline & {$[1.08]$} & {$[1.99]^{2}$} & [0.33] & {$[0.16]$} & {$[1.58]$} & {$[2.70]^{3}$} & {$[1.96]^{2}$} & {$[3.62]^{3}$} \\
\hline \multirow[t]{2}{*}{ Experience $\mathrm{x}$ D8 } & 0,0058 & $-0,0019$ & $-0,0022$ & $-0,0011$ & $-0,0031$ & $-0,0001$ & $-0,0015$ & $-0,0032$ \\
\hline & [1.45] & {$[0.44]$} & {$[0.66]$} & {$[0.40]$} & [1.27] & {$[0.03]$} & [0.59] & [1.58] \\
\hline \multirow[t]{2}{*}{ Experience x D11 } & $-0,0124$ & $-0,0055$ & $-0,0004$ & $-0,0001$ & $-0,0059$ & $-0,0132$ & $-0,0099$ & 0,0023 \\
\hline & {$[3.14]^{3}$} & {$[1.37]$} & {$[0.14]$} & {$[0.04]$} & {$[2.36]^{2}$} & {$[4.71]^{3}$} & {$[4.07]^{3}$} & {$[1.21]$} \\
\hline \multirow[t]{2}{*}{ Experience x D15 } & $-0,0093$ & $-0,0041$ & $-0,0052$ & $-0,0124$ & $-0,0097$ & $-0,0074$ & $-0,0042$ & $-0,006$ \\
\hline & {$[1.94]^{1}$} & {$[0.77]$} & {$[1.22]$} & {$[3.43]^{3}$} & {$[3.57]^{3}$} & {$[2.21]^{2}$} & {$[1.32]$} & {$[2.35]^{2}$} \\
\hline \multirow[t]{2}{*}{ Schooling $=16$} & 0,1644 & $-0,0224$ & 0,0143 & 0,151 & 0,1403 & 0,1121 & $-0,0313$ & $-0,1207$ \\
\hline & {$[2.44]^{2}$} & {$[0.30]$} & {$[0.22]$} & {$[2.70]^{3}$} & {$[3.68]^{3}$} & {$[2.26]^{2}$} & {$[0.77]$} & {$[3.54]^{3}$} \\
\hline \multirow[t]{2}{*}{ D4 x (S-4) } & $-0,0103$ & $-0,0364$ & $-0,0142$ & $-0,0063$ & 0,0221 & $-0,0076$ & 0,0349 & 0,0211 \\
\hline & {$[0.61]$} & {$[1.80]^{1}$} & {$[0.92]$} & {$[0.47]$} & {$[2.18]^{2}$} & {$[0.62]$} & {$[2.95]^{3}$} & {$[2.02]^{2}$} \\
\hline \multirow[t]{2}{*}{ D8 $x(S-8)$} & 0,0192 & 0,001 & 0,0197 & $-0,015$ & $-0,0065$ & 0,0495 & 0,0209 & $-0,0021$ \\
\hline & {$[0.55]$} & {$[0.03]$} & {$[0.78]$} & {$[0.73]$} & {$[0.30]$} & {$[2.36]^{2}$} & [1.18] & {$[0.14]$} \\
\hline \multirow[t]{2}{*}{ D11 $x(S-11)$} & 0,1089 & 0,2126 & 0,1497 & 0,2222 & 0,0449 & 0,0388 & 0,1112 & 0,1603 \\
\hline & {$[2.89]^{3}$} & {$[5.18]^{3}$} & {$[4.81]^{3}$} & {$[9.62]^{3}$} & {$[1.92]^{1}$} & {$[1.64]$} & {$[5.58]^{3}$} & {$[9.68]^{3}$} \\
\hline \multirow[t]{2}{*}{ D15 x (S-15) } & $-0,0778$ & $-0,0157$ & 0,0642 & 0,036 & $-0,0146$ & 0,0078 & 0,062 & 0,101 \\
\hline & {$[1.64]$} & {$[0.29]$} & {$[1.44]$} & {$[0.92]$} & {$[0.48]$} & {$[0.23]$} & {$[2.07]^{2}$} & {$[4.66]^{3}$} \\
\hline Woman & $-0,638$ & $-0,4863$ & $-0,3628$ & $-0,3112$ & $-0,5245$ & $-0,4514$ & $-0,3609$ & $-0,3576$ \\
\hline & {$[41.39]^{3}$} & {$[27.65]^{3}$} & {$[27.43]^{3}$} & {$[26.32]^{3}$} & {$[56.64]^{3}$} & {$[41.95]^{3}$} & {$[37.02]^{3}$} & {$[43.38]^{3}$} \\
\hline Black & $-0,0969$ & $-0,129$ & $-0,1159$ & $-0,1022$ & $-0,1789$ & $-0,1737$ & $-0,1784$ & $-0,1655$ \\
\hline & {$[6.64]^{3}$} & {$[7.13]^{3}$} & {$[8.04]^{3}$} & {$[8.15]^{3}$} & {$[19.80]^{3}$} & {$[16.05]^{3}$} & {$[18.03]^{3}$} & {$[19.80]^{3}$} \\
\hline Constant & 1,5992 & 1,1156 & 1,2679 & 1,1121 & 1,8984 & 1,6675 & 1,9944 & 1,6496 \\
\hline & {$[28.58]^{3}$} & {$[14.73]^{3}$} & {$[21.10]^{3}$} & {$[19.39]^{3}$} & {$[44.99]^{3}$} & {$[27.32]^{3}$} & {$[33.16]^{3}$} & {$[31.04]^{3}$} \\
\hline F-test for sheepskin effects $=0$ & 5,990 & 7,780 & 4,110 & 6,610 & 8,810 & 10,610 & 10,090 & 11,380 \\
\hline Prob $>F$ & 0,000 & 0,000 & 0,003 & 0,000 & 0,000 & 0,000 & 0,000 & 0,000 \\
\hline F-test for splines $=0$ & 7,500 & 15,210 & 19,420 & 50,530 & 5,340 & 9,800 & 42,290 & 88,880 \\
\hline Prob $>F$ & 0,000 & 0,000 & 0,000 & 0,000 & 0,000 & 0,000 & 0,000 & 0,000 \\
\hline Observations & 15402 & 13357 & 16499 & 22378 & 27592 & 21044 & 22791 & 26949 \\
\hline R-squared & 0,49 & 0,39 & 0,43 & 0,40 & 0,52 & 0,42 & 0,45 & 0,44 \\
\hline
\end{tabular}

${ }^{a}$ Note: Robust t-statistics in brackets.

${ }^{1}$ significant at $10 \%$.

2 significant at $5 \%$.

${ }^{3}$ significant at $1 \%$. 
Table A-3: Descriptive statistics

\begin{tabular}{|l|c|c|c|c|}
\hline & 1982 & 1992 & 1998 & 2004 \\
\hline Center-west & & & & \\
Earnings in the main job & 682,68 & 446,98 & 624,95 & 517,07 \\
Hourly earnings in the main job & $(957.25)$ & 686,066 & 1037,66 & 1004,889 \\
& 16,51 & 11,79 & 17,35 & 14,37 \\
Years of schooling & $(25.31)$ & $(17.67)$ & $(43.59)$ & $(32.32)$ \\
& 5,46 & 6,45 & 7,11 & 7,88 \\
Age & $(4.75)$ & $(4.66)$ & $(4.52)$ & $(4.51)$ \\
& 37,17 & 37,18 & 37,81 & 38,17 \\
Experience & $(9.16)$ & $(9.05)$ & $(9.07)$ & $(9.20)$ \\
& 24,39 & 23,71 & 24,12 & 24,17 \\
Number of observations & $(10.51)$ & $(10.24)$ & $(10.39)$ & $(10.50)$ \\
\hline North & & 7499 & 8835 & 12030 \\
Earnings in the main job & & & & \\
Hourly earnings in the main job & 607,91 & 361,02 & 487,18 & 367,57 \\
& $(730,96)$ & $(460,36)$ & $(694,62)$ & $(510,30)$ \\
Years of schooling & 14,67 & 9,89 & 13,39 & 10,50 \\
Number of observations & $(24,08)$ & $(15,42)$ & $(22,48)$ & $(18,91)$ \\
Age & 5,17 & 6,14 & 6,48 & 7,49 \\
Experience & $(4,34)$ & $(4,47)$ & $(4,51)$ & $(4,42)$ \\
Number of observations & 37,28 & 37,10 & 37,92 & 37,71 \\
South & $(9,35)$ & $(9,18)$ & $(9,05)$ & $(9,08)$ \\
Earnings in the main job & 24,15 & 22,72 & 23,87 & 23,12 \\
Ygears of schooling & $(10,85)$ & $(10,63)$ & $(10,42)$ & $(10,44)$ \\
& & & & \\
\hline & & & & \\
& $(859,19$ & 497,79 & 618,09 & 479,72 \\
& 15,79 & $(1201,20)$ & $(859,76)$ & $(648,93)$ \\
& $(21,81)$ & $(27,04)$ & $(24,05)$ & $(21,08)$ \\
& 5,60 & 6,66 & 7,26 & 8,24 \\
& $(4,40)$ & $(4,41)$ & $(4,37)$ & $(4,34)$ \\
& 37,58 & 37,76 & 38,50 & 39,14 \\
& $(9,33)$ & $(9,09)$ & $(9,04)$ & $(9,34)$ \\
& 24,51 & 23,67 & 24,68 & 24,94 \\
& $(10,65)$ & $(10,29)$ & $(10,15)$ & $(10,50)$ \\
& 14946 & 12792 & 14789 & 17772 \\
\hline
\end{tabular}

: Notes: based on PNAD data for individuals aged 25 to 60 years old, living in urban area, who are the head of the household or the spouse of the head. Standard errors are in parenteses. Earnings in 1999 Reais. 
Figure A-1: Educational distribution
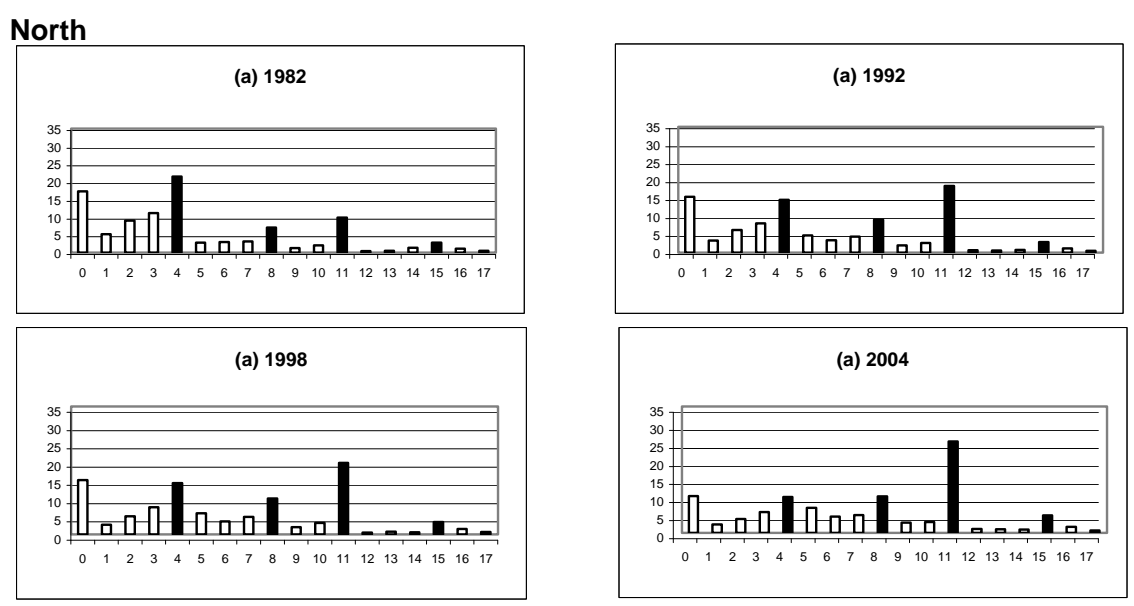

South
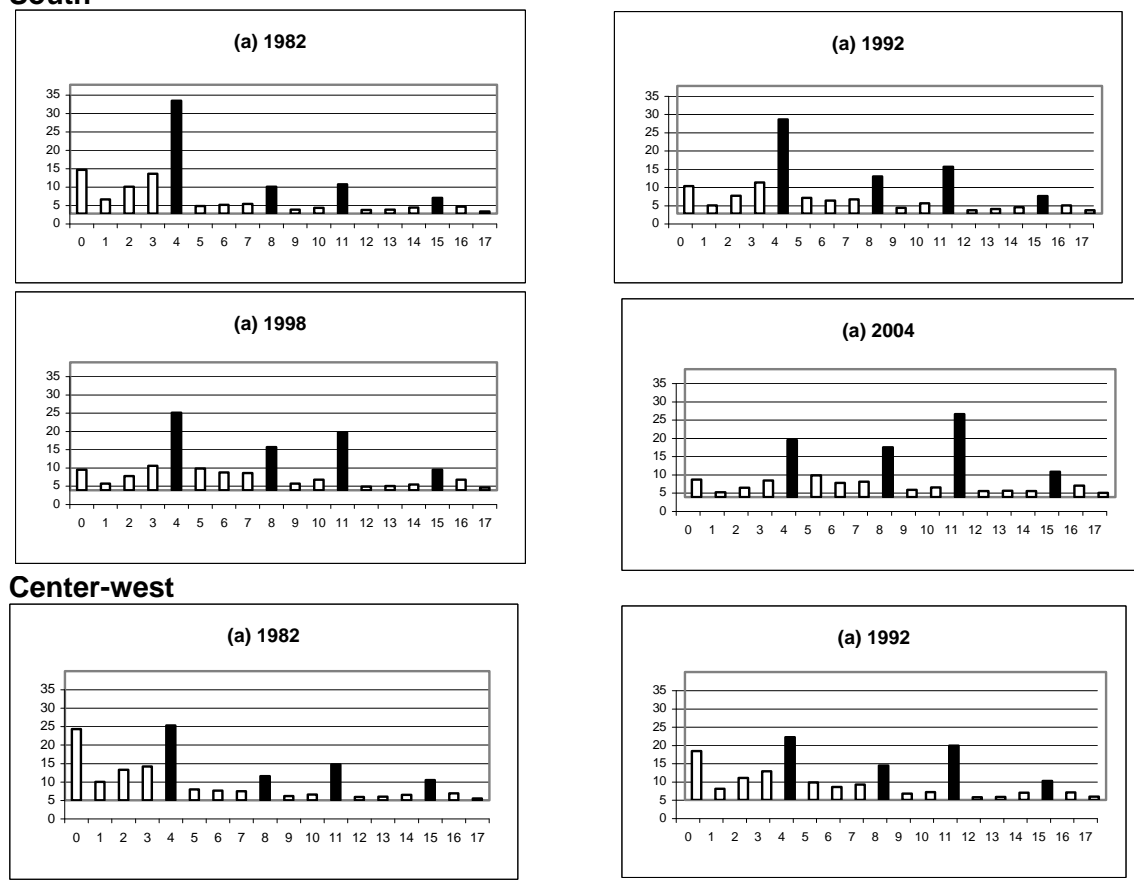

(a) 1998
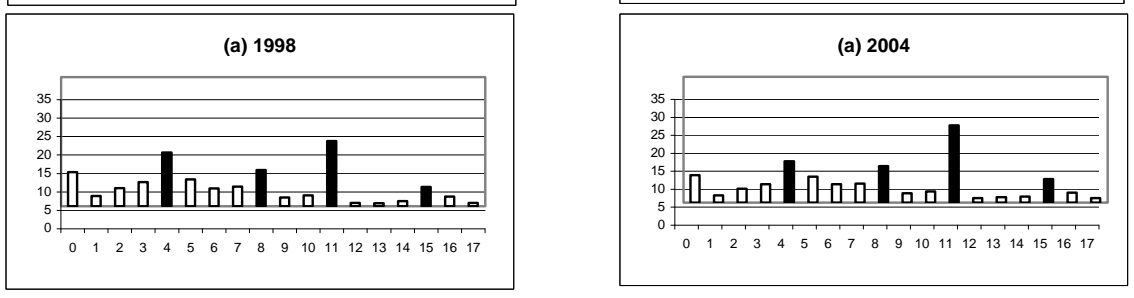
Table A-4: Earnings equation - North

\begin{tabular}{|c|c|c|c|c|}
\hline \multicolumn{5}{|c|}{ Dependent variable: log of earnings in the main job } \\
\hline & 1982 & 1992 & 1998 & 2004 \\
\hline & (1) & $(2)$ & (3) & (4) \\
\hline \multirow[t]{2}{*}{ Years of schooling $(\mathrm{S})$} & 0,0495 & $-0,065$ & 0,0334 & 0,0714 \\
\hline & {$[1.81]^{1}$} & {$[1.71]^{1}$} & [0.95] & {$[2.87]^{3}$} \\
\hline \multirow{2}{*}{ Experience } & $-0,0013$ & 0,008 & 0,0143 & 0,0212 \\
\hline & {$[0.28]$} & [1.19] & {$[2.26]^{2}$} & {$[4.95]^{3}$} \\
\hline \multirow[t]{2}{*}{ Experience squared } & $-0,0001$ & $-0,0002$ & $-0,0003$ & $-0,0003$ \\
\hline & {$[1.12]$} & {$[2.23]^{2}$} & {$[2.77]^{3}$} & {$[4.80]^{3}$} \\
\hline \multirow[t]{2}{*}{ Experience $\mathrm{x}$ schooling } & 0,0007 & 0,0046 & 0,0016 & $-0,0003$ \\
\hline & {$[0.80]$} & {$[3.98]^{3}$} & [1.47] & [0.35] \\
\hline \multirow[t]{2}{*}{ Lower primary (D4) } & $-0,111$ & 0,4838 & $-0,0501$ & $-0,0405$ \\
\hline & [1.13] & {$[3.26]^{3}$} & {$[0.37]$} & [0.37] \\
\hline \multirow[t]{2}{*}{ Upper primary (D8) } & 0,077 & 0,5483 & 0,1446 & 0,0378 \\
\hline & {$[0.67]$} & {$[4.13]^{3}$} & [1.11] & {$[0.42]$} \\
\hline \multirow[t]{2}{*}{ Secondary school (D11) } & 0,30 & 0,5511 & 0,295 & 0,2851 \\
\hline & {$[2.54]^{2}$} & {$[3.74]^{3}$} & {$[2.22]^{2}$} & {$[3.51]^{3}$} \\
\hline \multirow[t]{2}{*}{ College (D15) } & 0,4938 & 0,1937 & 0,4706 & 0,3075 \\
\hline & {$[3.37]^{3}$} & {$[0.85]$} & {$[2.20]^{2}$} & {$[2.58]^{3}$} \\
\hline \multirow[t]{2}{*}{ Experience x D4 } & 0,0079 & $-0,013$ & 0,0033 & 0,0029 \\
\hline & {$[2.30]^{2}$} & {$[2.58]^{3}$} & {$[0.71]$} & {$[0.77]$} \\
\hline \multirow[t]{2}{*}{ Experience x D8 } & $-0,0016$ & $-0,0173$ & $-0,0041$ & 0,0045 \\
\hline & {$[0.31]$} & {$[2.85]^{3}$} & {$[0.74]$} & [1.22] \\
\hline \multirow[t]{2}{*}{ Experience x D11 } & 0,0005 & $-0,0177$ & $-0,0081$ & 0,002 \\
\hline & {$[0.10]$} & {$[3.09]^{3}$} & {$[1.66]^{1}$} & {$[0.64]$} \\
\hline \multirow[t]{2}{*}{ Experience x D15 } & $-0,0161$ & $-0,018$ & $-0,0198$ & $-0,0135$ \\
\hline & {$[2.77]^{3}$} & {$[2.42]^{2}$} & {$[2.80]^{3}$} & {$[3.07]^{3}$} \\
\hline \multirow[t]{2}{*}{ Schooling $=16$} & 0,1088 & $-0,0492$ & 0,0624 & 0,0173 \\
\hline & [1.26] & [0.46] & {$[0.67]$} & [0.23] \\
\hline \multirow[t]{2}{*}{ D4 x (S-4) } & 0,0163 & $-0,0025$ & 0,0044 & $-0,0548$ \\
\hline & {$[0.75]$} & [0.09] & {$[0.18]$} & {$[3.06]^{3}$} \\
\hline \multirow[t]{2}{*}{ D8 x (S-8) } & $-0,0189$ & 0,0813 & 0,0376 & 0,0104 \\
\hline & [0.49] & {$[1.97]^{2}$} & [1.01] & [0.43] \\
\hline \multirow[t]{2}{*}{ D11 x (S-11) } & 0,0556 & 0,0814 & 0,086 & 0,1933 \\
\hline & {$[1.29]$} & {$[1.48]$} & {$[1.73]^{1}$} & {$[7.04]^{3}$} \\
\hline \multirow[t]{2}{*}{ D15 x (S-15) } & $-0,0298$ & $-0,054$ & 0,012 & 0,107 \\
\hline & {$[0.48]$} & {$[0.66]$} & {$[0.17]$} & {$[1.86]^{1}$} \\
\hline \multirow[t]{2}{*}{ Woman } & $-0,789$ & $-0,65$ & $-0,5995$ & $-0,5343$ \\
\hline & {$[37.00]^{3}$} & {$[24.83]^{3}$} & {$[26.72]^{3}$} & {$[37.13]^{3}$} \\
\hline \multirow[t]{2}{*}{ Black } & $-0,1283$ & $-0,1769$ & $-0,1538$ & $-0,1612$ \\
\hline & {$[6.03]^{3}$} & {$[6.58]^{3}$} & {$[6.17]^{3}$} & {$[9.66]^{3}$} \\
\hline \multirow[t]{2}{*}{ Constant } & 6,0524 & 5,3442 & 5,416 & 5,1195 \\
\hline & {$[75.86]^{3}$} & {$[44.92]^{3}$} & {$[46.08]^{3}$} & {$[67.22]^{3}$} \\
\hline F-test for sheepskin effects $=0$ & 6,840 & 7,740 & 3,190 & 5,750 \\
\hline Prob $>F$ & 0,000 & 0,000 & 0,013 & 0,000 \\
\hline F-test for splines $=0$ & 0,930 & 4,480 & 3,630 & 28,140 \\
\hline Prob $>$ F & 0,447 & 0,001 & 0,006 & 0,000 \\
\hline Observations & 6300 & 4201 & 5127 & 9928 \\
\hline R-squared & 0,45 & 0,38 & 0,41 & 0,41 \\
\hline
\end{tabular}

${ }^{a}$ Note: Robust t-statistics in brackets.

${ }^{1}$ significant at $10 \%$.

2 significant at 5\%.

${ }^{3}$ significant at $1 \%$. 
Table A-5: Earnings equation - South

\begin{tabular}{|c|c|c|c|c|}
\hline \multicolumn{5}{|c|}{ Dependent variable: log of earnings in the main job } \\
\hline & 1982 & 1992 & 1998 & 2004 \\
\hline & (1) & (2) & (3) & (4) \\
\hline \multirow[t]{2}{*}{ Years of schooling $(S)$} & 0,0811 & 0,002 & 0,0588 & 0,0241 \\
\hline & {$[3.53]^{3}$} & {$[0.07]$} & {$[2.18]^{2}$} & {$[0.97]$} \\
\hline \multirow[t]{2}{*}{ Experience } & 0,0248 & 0,0167 & 0,0193 & 0,0181 \\
\hline & {$[6.10]^{3}$} & {$[3.33]^{3}$} & {$[4.12]^{3}$} & {$[4.44]^{3}$} \\
\hline \multirow[t]{2}{*}{ Experience squared } & $-0,0005$ & $-0,0004$ & $-0,0004$ & $-0,0003$ \\
\hline & {$[7.25]^{3}$} & {$[5.83]^{3}$} & {$[5.83]^{3}$} & {$[5.87]^{3}$} \\
\hline \multirow[t]{2}{*}{ Experience $\mathrm{x}$ schooling } & 0,0008 & 0,0028 & 0,0007 & 0,0015 \\
\hline & {$[1.11]$} & {$[3.43]^{3}$} & {$[0.85]$} & {$[2.20]^{2}$} \\
\hline \multirow[t]{2}{*}{ Lower primary (D4) } & 0,185 & 0,1728 & $-0,0425$ & 0,0413 \\
\hline & {$[2.48]^{2}$} & {$[1.88]^{1}$} & {$[0.44]$} & {$[0.41]$} \\
\hline \multirow[t]{2}{*}{ Upper primary (D8) } & $-0,0363$ & 0,2676 & 0,009 & 0,2806 \\
\hline & {$[0.40]$} & {$[2.77]^{3}$} & {$[0.10]$} & {$[3.57]^{3}$} \\
\hline \multirow[t]{2}{*}{ Secondary school (D11) } & 0,2919 & 0,48 & 0,3666 & 0,2329 \\
\hline & {$[2.81]^{3}$} & {$[4.53]^{3}$} & {$[3.97]^{3}$} & {$[3.07]^{3}$} \\
\hline \multirow[t]{2}{*}{ College (D15) } & 0,2663 & 0,267 & 0,2777 & 0,2368 \\
\hline & {$[2.65]^{3}$} & {$[2.15]^{2}$} & {$[2.29]^{2}$} & {$[2.40]^{2}$} \\
\hline \multirow[t]{2}{*}{ Experience x D4 } & $-0,0036$ & $-0,003$ & 0,004 & $-0,0003$ \\
\hline & [1.39] & {$[0.97]$} & {$[1.34]$} & {$[0.10]$} \\
\hline \multirow[t]{2}{*}{ Experience x D8 } & 0,0019 & $-0,0061$ & 0,0031 & $-0,0091$ \\
\hline & {$[0.47]$} & {$[1.48]$} & {$[0.85]$} & {$[2.95]^{3}$} \\
\hline \multirow[t]{2}{*}{ Experience x D11 } & $-0,0082$ & $-0,0158$ & $-0,0102$ & $-0,0024$ \\
\hline & {$[2.03]^{2}$} & {$[3.82]^{3}$} & {$[3.00]^{3}$} & {$[0.86]$} \\
\hline \multirow[t]{2}{*}{ Experience x D15 } & $-0,0026$ & $-0,0132$ & $-0,0086$ & $-0,0087$ \\
\hline & {$[0.53]$} & {$[2.49]^{2}$} & {$[1.95]^{1}$} & {$[2.35]^{2}$} \\
\hline \multirow[t]{2}{*}{ Schooling $=16$} & 0,0742 & 0,0952 & $-0,0504$ & $-0,1205$ \\
\hline & {$[1.33]$} & {$[1.33]$} & {$[0.83]$} & {$[2.51]^{2}$} \\
\hline \multirow[t]{2}{*}{ D4 x (S-4) } & 0,0027 & $-0,0068$ & $-0,0111$ & $-0,014$ \\
\hline & {$[0.15]$} & {$[0.36]$} & {$[0.64]$} & {$[0.80]$} \\
\hline \multirow[t]{2}{*}{$\mathrm{D} 8 \mathrm{x}(\mathrm{S}-8)$} & 0,0104 & 0,0297 & 0,0307 & 0,0137 \\
\hline & {$[0.35]$} & {$[1.06]$} & {$[1.37]$} & {$[0.67]$} \\
\hline \multirow[t]{2}{*}{ D11 x (S-11) } & $-0,0137$ & 0,0436 & 0,0479 & 0,1127 \\
\hline & [0.43] & [1.39] & {$[1.81]^{1}$} & {$[5.10]^{3}$} \\
\hline \multirow[t]{2}{*}{ D15 x (S-15) } & 0,0088 & 0,0682 & 0,0876 & 0,1258 \\
\hline & {$[0.21]$} & {$[1.34]$} & {$[2.14]^{2}$} & {$[4.02]^{3}$} \\
\hline \multirow[t]{2}{*}{ Woman } & $-0,7882$ & $-0,7112$ & $-0,6498$ & $-0,601$ \\
\hline & {$[47.68]^{3}$} & {$[42.21]^{3}$} & {$[46.70]^{3}$} & {$[50.74]^{3}$} \\
\hline \multirow[t]{2}{*}{ Black } & $-0,1719$ & $-0,1533$ & $-0,1683$ & $-0,1411$ \\
\hline & {$[9.19]^{3}$} & {$[6.86]^{3}$} & {$[9.11]^{3}$} & {$[9.38]^{3}$} \\
\hline \multirow[t]{2}{*}{ Constant } & 5,4583 & 5,3869 & 5,5152 & 5,2996 \\
\hline & {$[77.60]^{3}$} & {$[55.94]^{3}$} & {$[59.35]^{3}$} & {$[62.89]^{3}$} \\
\hline F-test for sheepskin effects $=0$ & 4,570 & 6,690 & 6,590 & 5,500 \\
\hline Prob $>F$ & 0,001 & 0,000 & 0,000 & 0,000 \\
\hline F-test for splines $=0$ & 0,060 & 4,490 & 7,700 & 29,270 \\
\hline Prob $>F$ & 0,993 & 0,001 & 0,000 & 0,000 \\
\hline Observations & 12355 & 10700 & 12245 & 14832 \\
\hline R-squared & 0,52 & 0,41 & 0,44 & 0,42 \\
\hline
\end{tabular}

${ }^{a}$ Note: Robust t-statistics in brackets.

${ }^{1}$ significant at $10 \%$.

2 significant at $5 \%$.

${ }^{3}$ significant at $1 \%$. 
Table A-6: Earnings equation Center-west

\begin{tabular}{|c|c|c|c|c|}
\hline \multicolumn{5}{|c|}{ Dependent variable: log of earnings in the main job } \\
\hline & 1982 & 1992 & 1998 & 2004 \\
\hline & (1) & (2) & (3) & (4) \\
\hline \multirow[t]{2}{*}{ Years of schooling $(\mathrm{S})$} & 0,0664 & 0,0383 & 0,0068 & 0,0265 \\
\hline & {$[2.81]^{3}$} & {$[1.27]$} & {$[0.25]$} & {$[1.11]$} \\
\hline \multirow[t]{2}{*}{ Experience } & 0,0104 & 0,0157 & 0,005 & 0,0113 \\
\hline & {$[2.40]^{2}$} & {$[2.87]^{3}$} & {$[1.00]$} & {$[2.79]^{3}$} \\
\hline \multirow[t]{2}{*}{ Experience squared } & $-0,0002$ & $-0,0003$ & $-0,0002$ & $-0,0002$ \\
\hline & {$[3.34]^{3}$} & {$[3.93]^{3}$} & {$[2.47]^{2}$} & {$[3.99]^{3}$} \\
\hline \multirow[t]{2}{*}{ Experience $\mathrm{x}$ schooling } & 0,0017 & 0,0015 & 0,0019 & 0,0009 \\
\hline & {$[2.08]^{2}$} & {$[1.52]$} & {$[2.30]^{2}$} & {$[1.24]$} \\
\hline \multirow[t]{2}{*}{ Lower primary (D4) } & 0,1196 & $-0,1078$ & 0,0007 & $-0,0691$ \\
\hline & [1.32] & [0.93] & {$[0.01]$} & {$[0.71]$} \\
\hline \multirow[t]{2}{*}{ Upper primary (D8) } & 0,2629 & 0,3097 & 0,3623 & 0,1938 \\
\hline & {$[2.60]^{3}$} & {$[2.62]^{3}$} & {$[3.45]^{3}$} & {$[2.34]^{2}$} \\
\hline \multirow[t]{2}{*}{ Secondary school (D11) } & 0,4221 & 0,3741 & 0,3956 & 0,1499 \\
\hline & {$[3.73]^{3}$} & {$[3.08]^{3}$} & {$[3.83]^{3}$} & {$[1.87]^{1}$} \\
\hline \multirow[t]{2}{*}{ College (D15) } & 0,2325 & 0,2805 & 0,1332 & 0,1837 \\
\hline & {$[1.96]^{1}$} & {$[1.83]^{1}$} & {$[0.91]$} & [1.59] \\
\hline \multirow[t]{2}{*}{ Experience x D4 } & $-0,0004$ & 0,0039 & 0,0026 & 0,004 \\
\hline & {$[0.10]$} & {$[0.97]$} & {$[0.72]$} & {$[1.23]$} \\
\hline \multirow[t]{2}{*}{ Experience x D8 } & $-0,0082$ & $-0,0099$ & $-0,0108$ & $-0,0045$ \\
\hline & {$[1.88]^{1}$} & {$[1.99]^{2}$} & {$[2.52]^{2}$} & {$[1.42]$} \\
\hline \multirow[t]{2}{*}{ Experience x D11 } & $-0,0076$ & $-0,0102$ & $-0,0083$ & 0,001 \\
\hline & {$[1.70]^{1}$} & {$[2.15]^{2}$} & {$[2.04]^{2}$} & {$[0.32]$} \\
\hline \multirow[t]{2}{*}{ Experience x D15 } & $-0,0091$ & $-0,0047$ & $-0,006$ & $-0,0099$ \\
\hline & {$[1.78]^{1}$} & {$[0.77]$} & {$[1.18]$} & {$[2.34]^{2}$} \\
\hline \multirow[t]{2}{*}{ Schooling $=16$} & 0,0696 & 0,0427 & 0,0304 & 0,0846 \\
\hline & {$[1.05]$} & {$[0.50]$} & {$[0.40]$} & {$[1.40]$} \\
\hline \multirow[t]{2}{*}{ D4 x (S-4) } & $-0,0162$ & $-0,002$ & 0,0004 & $-0,0084$ \\
\hline & {$[0.87]$} & [0.09] & [0.02] & {$[0.52]$} \\
\hline \multirow[t]{2}{*}{$\mathrm{D} 8 \times(\mathrm{S}-8)$} & $-0,0349$ & 0,044 & 0,0268 & 0,0404 \\
\hline & {$[1.01]$} & [1.32] & {$[0.90]$} & {$[1.73]^{1}$} \\
\hline \multirow[t]{2}{*}{ D11 x (S-11) } & 0,1454 & 0,0411 & 0,1548 & 0,1608 \\
\hline & {$[3.88]^{3}$} & {$[1.12]$} & {$[4.24]^{3}$} & {$[6.07]^{3}$} \\
\hline \multirow[t]{2}{*}{ D15 x (S-15) } & $-0,1477$ & $-0,0092$ & $-0,0608$ & 0,0576 \\
\hline & {$[3.14]^{3}$} & {$[0.15]$} & [1.09] & {$[1.50]$} \\
\hline \multirow[t]{2}{*}{ Woman } & $-0,8387$ & $-0,6843$ & $-0,6668$ & $-0,6177$ \\
\hline & {$[46.36]^{3}$} & {$[34.69]^{3}$} & {$[39.68]^{3}$} & {$[44.29]^{3}$} \\
\hline \multirow[t]{2}{*}{ Black } & $-0,0873$ & $-0,0941$ & $-0,0949$ & $-0,1356$ \\
\hline & {$[5.58]^{3}$} & {$[4.94]^{3}$} & {$[5.59]^{3}$} & {$[9.77]^{3}$} \\
\hline \multirow[t]{2}{*}{ Constant } & 5,5968 & 5,2684 & 5,7257 & 5,4691 \\
\hline & {$[79.48]^{3}$} & {$[55.99]^{3}$} & {$[64.14]^{3}$} & {$[72.36]^{3}$} \\
\hline F-test for sheepskin effects $=0$ & 5,230 & 7,370 & 7,970 & 4,000 \\
\hline Prob $>F$ & 0,000 & 0,000 & 0,000 & 0,003 \\
\hline F-test for splines $=0$ & 6,340 & 3,360 & 12,990 & 36,320 \\
\hline Prob $>F$ & 0,000 & 0,009 & 0,000 & 0,000 \\
\hline Observations & 9717 & 6229 & 7227 & 9880 \\
\hline R-squared & 0,56 & 0,46 & 0,48 & 0,48 \\
\hline
\end{tabular}

${ }^{a}$ Note: Robust t-statistics in brackets.

${ }^{1}$ significant at $10 \%$.

2 significant at $5 \%$.

${ }^{3}$ significant at $1 \%$. 
Figure A-2: Estimated profiles of years of completed schooling and log earnings
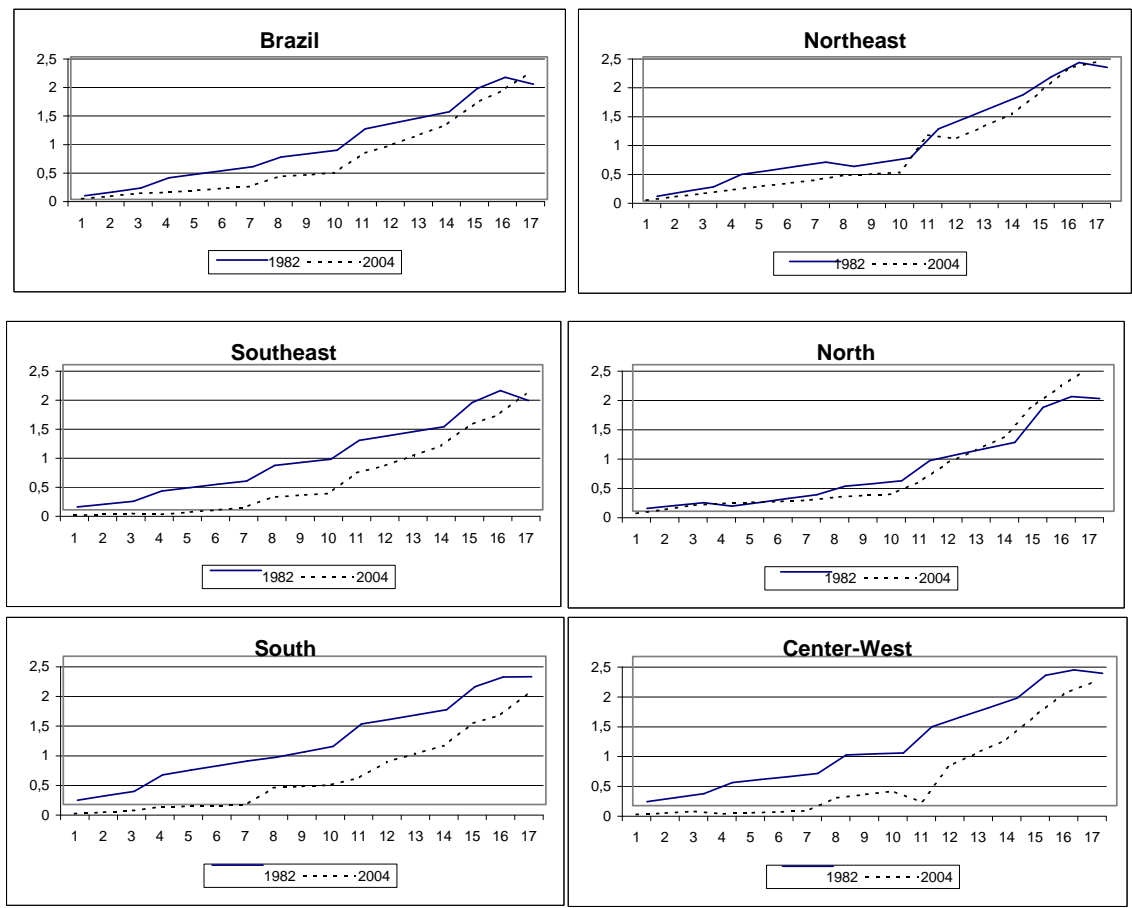
Figure A-3: Estimated profiles of years of completed schooling and log earnings - semiparametric regressions
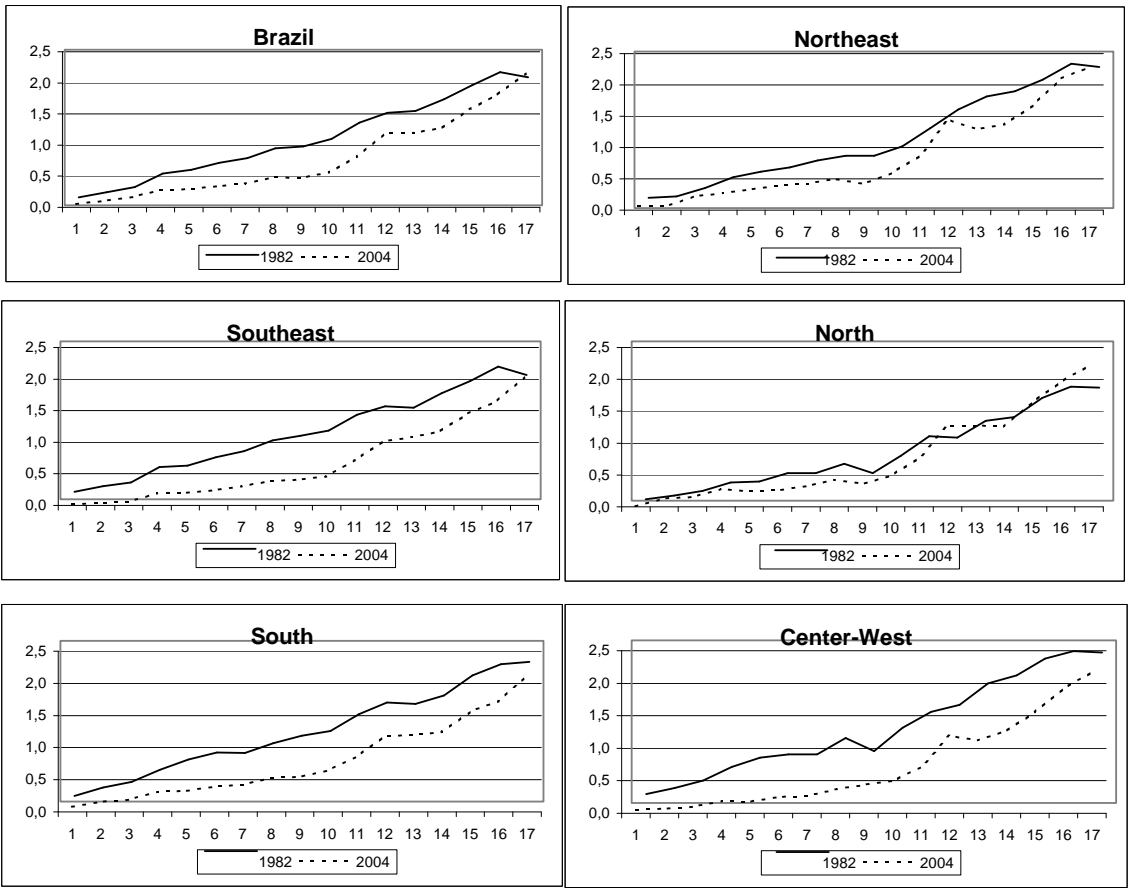